Eastern Illinois University

The Keep

Faculty Research and Creative Activity

Early Childhood, Elementary \& Middle Level

Education

April 2014

\title{
Trade books' Historical Representation of Eleanor Roosevelt, Rosa Parks, and Helen Keller
}

John H. Bickford III

Eastern Illinois University, jbickford@eiu.edu

Cynthia W. Rich

Eastern Illinois University, cwrich@eiu.edu

Follow this and additional works at: http://thekeep.eiu.edu/eemedu_fac

Cart of the Education Commons

\section{Recommended Citation}

Bickford, John H. III and Rich, Cynthia W., "Trade books' Historical Representation of Eleanor Roosevelt, Rosa Parks, and Helen Keller" (2014). Faculty Research and Creative Activity. 29.

http://thekeep.eiu.edu/eemedu_fac/29

This Article is brought to you for free and open access by the Early Childhood, Elementary \& Middle Level Education at The Keep. It has been accepted for inclusion in Faculty Research and Creative Activity by an authorized administrator of The Keep. For more information, please contact tabruns@eiu.edu. 


\title{
Trade books' Historical Representation of Eleanor Roosevelt, Rosa Parks, and Helen Keller
}

\author{
John H. Bickford III \\ Cynthia W. Rich \\ Eastern Illinois University
}

Common Core State Standards Initiative mandates increased readings of informational texts within English Language Arts starting in elementary school. Accurate, age-appropriate, and engaging content is at the center of effective social studies teaching. Textbooks and children's literature - both literary and informational-are prominent in elementary classrooms because of the esoteric nature of primary source material. Many research projects have investigated historical accuracy and representation within textbooks, but few have done so with children's trade books. We examined children's trade books centered on three historical figures frequently incorporated within elementary school curricula: Eleanor Roosevelt, Rosa Parks, and Helen Keller. Findings revealed various forms of historical misrepresentation and differing levels of historicity. Reporting such lacunae is important for those involved in curricular decisions. We believe children's books, even those with historical omissions and misrepresentations, provide an unique opportunity for students to incorporate and scrutinize diverse perspectives as they actively assemble historical understandings. All secondary narratives, even historically representative children's books, can benefit from primary source supplementation. We guide teachers interested in employing relevant and rich primary source material.

Key Words: Children's literature, Eleanor Roosevelt, Rosa Parks, Helen Keller, primary sources, informational texts

\section{Introduction}

Social studies education aims to prepare students for college and career along with active, constructive civic participation in a democratic society (Common Core State Standards Initiative [CCSSI], 2010; Council of Chief State School Officers [CCSSO], 2012; National Council for the Social Studies [NCSS], 2013; Parker, 2010). Students' historical thinking and examination of primary source material contributes towards this aim (Bickford, 2013b; Nokes, 2011; Wineburg, 2007). Historical thinking, however, is not innate and must be cultivated and sharpened (Wineburg, 2001). While both national and case study research have revealed time reductions for social studies in elementary schools (Center on Education Policy, 2008; Wilton \& Bickford, 2012), federal and state initiatives are intended to curb this reduction. From the earliest of elementary grades through high school, Common Core prescribes intensive readings of informational texts within the English Language Arts curricula, history, social studies curricula (CCSSI; NCSS). Students' historical literacy, thus, is integrated across grades and disciplines in a model of shared responsibility for college, career, and civic preparedness (CCSSI; CCSSO; NCSS). To foster developmentally appropriate historical thinking, elementary social studies education researchers encourage teachers to immerse young students in historical and informational texts. While historians utilize primary historical documents and secondary accounts to better understand history, such material is not readily comprehensible for elementary students. Teachers thus rely on textbooks, primary source material, and trade books. 
Social studies education researchers have examined textbooks' content for accuracy and found both regrettable inaccuracies and conspicuous omissions (Chick, 2006; Loewen, 1995), with most being inadvertent and some deriving from publishers' purposeful diminishment of contentious content (Matusevich, 2006). Textbooks' relatively dry and omnipotent narratives neglect the divergent historical interpretations and multiple, competing perspectives prominent in the history field (Lindquist, 2009; Wineburg, 2001, Wineburg \& Martin, 2009). Classroom teachers' rely heavily on textbooks, which results in detached and disinterested readers (Fitzgerald, 2009; Loewen, 2010). Social studies education researchers therefore encourage students' examination of primary sources to supplement textbooks (Nokes, 2011; Wineburg, Martin, \& Monte-Sano, 2011).

Primary sources, rich in detail and perspective, are both the clay of historians' craft and compulsory for historical thinking (Wineburg, 2001; Wineburg et al., 2011). To actively assemble understandings, historians scrutinize a source for bias, intent, and message. They also weigh divergent accounts and evaluate the credibility of a source. Historical thinking can be initiated in elementary school (Bickford, 2013b; Baildon \& Baildon, 2012). Primary sources can be modified to improve accessibility for young, struggling, or inexperienced students (Bickford \& Wilton, 2012; Drake \& Brown, 2003; Wineburg \& Martin, 2009), yet elementary and middle level teachers rarely employ such materials (Wilton \& Bickford, 2012; Wineburg \& Martin). Elementary educators frequently use history-based trade books.

Rich in detail and narrow in coverage, trade books are more similar to primary sources than textbooks. Trade books have engaging narratives, varied reading levels, a wide range of topics, and a relatively low cost; new books covering different topics are published annually and gender representations have become more balanced (Chick \& Corle, 2012; Chick, Slekar, \& Charles, 2010). Trade books, however, have demonstrated inconsistent historicity (Bickford, 2013a; Powers, 2003; Williams, 2009). While trade books should not be held to the same standard of historical authenticity as textbooks (Collins \& Graham, 2001; Lathey, 2001; Rycik \& Rosler, 2009), historical misrepresentations must not remain unchallenged. It is unrealistic to expect every trade book to comprehensively cover every relevant historical aspect, yet it is sensible to avoid books with egregious lacunae and misrepresentation. Even a historically representative trade book, when used alone, lends itself to comprehension not historical inquiry (Bickford). A precisely spiraled curriculum is impossible when trade books are used as replacements for social studies curricula (Wilton \& Bickford, 2012). Researchers, therefore, must examine the historicity of the engaging literature that teachers seek and frequently utilize.

This project explores how children's trade books historically represent Eleanor Roosevelt, Rosa Parks, and Helen Keller. Recognized for their significant historical contributions, they each top many surveys of famous American women (Wineburg, 2008; Wineburg \& Monte-Sano, 2008). Roosevelt, Parks, and Keller hold an ubiquitous location within elementary social studies curricula due, in part, to their association with a themed month. While all three could be celebrated within Women's History Month, Parks's inclusion in African American History Month and Keller's insertion in National Deaf History Month or Disability Awareness Month seem logical. Findings from this study demonstrated, however, that trade books inconsistently portrayed Roosevelt, Keller, and Parks. Historical misrepresentations appeared to varying degrees. Only one woman was reliably historicized in the majority of trade books. 
These historical misrepresentations include, but are not limited to: presentism, exceptionalism, heroification, and omission (Bickford, 2013a; Loewen, 1995; Nokes, 2011; Wineburg, 2001). Presentism emerges when contemporary understandings shape the assessment of the past. To utilize information that historical figures were unaware of or to characterize the historical chain of events as inescapable is presentism. Exceptionalism manifests when an anomalous historical figure is portrayed as representative. To characterize the extraordinary as the typical is exceptionalism. Heroification surfaces when a historical figure is gratuitously credited at the expense of the collective efforts of many. To assign entirely more recognition than is deserved is heroification. Omission appears when a narrative disregards relevant events and considerations. To exchange complexity and accuracy for simplicity in a historical narrative is omission. Such lacunae are ubiquitous.

\section{Method}

Our research utilized best practice qualitative research methods to generate a sizeable, representative data pool of relatively current books inclusive of various genres and with elementary students as intended audiences (Kline, 2008, Krippendorff, 2013; Maxwell, 2010). To establish such a pool, we collected the titles of all trade books-expository, narrative nonfiction, graphic novel, and historical fiction - published in the last twenty-five years that centered on Roosevelt, Keller, or Parks with a suggested reading level between first and eighth grade. Each historical figure had between 70 and 100 books meeting the above criteria. Roosevelt had the least $(n=71)$ and Keller had the most $(n=98)$. From this initial pool, 15 books for each historical figure were randomly selected (see Appendix I for complete list). The genres of the selected titles proportionally represented the ratios of publication. The selected and analyzed Roosevelt books almost all were non-fiction, either expository or narrative non-fiction $(n=14)$; the Keller books were entirely non-fiction $(n=15)$; the Parks books had some variance in genre with the majority being non-fiction $(n=12)$ and some historical fiction $(n=2)$ and a graphic novel $(n=1)$.

We implemented rigorous qualitative research methods to generate empirical findings (Pillow 2003; Wineburg, 1998). Specifically, I (John) read each book and reflexively documented observable patterns of historical representation and misrepresentation along with variances in the patterns (Bickford, 2013a; Kline, 2008). We noted, for instance, the frequency of social segregation and absence of economic segregation in the Rosa Parks books. We then discussed these patterns and sought to test their presence. During a second reading of each book, I scrutinized the emergent patterns and anomalies for accuracy. This inductive analysis established the codes, or working hypotheses (Chick \& Corle, 2012; Wineburg). We then discussed and synthesized the codes to generate a content analysis tool, which I used during a third critical rereading of each book. Using the newly generated content analysis tool, the third reading verified the dependability of the codes and relevancy of findings. The content analysis tool for each historical figure differed considerably, which Table 1 reports. In the last step, we only reported those findings that were historically significant and empirically grounded (Chick, Slekar, \& Charles, 2010; Krippendorff, 2013). We jettisoned, for instance, the data collected relative to the specific mentioning of Mademoiselle Souvestre, Eleanor Roosevelt's most influential teacher; it seemed to be minutiae. 
Table 1

Content Analysis Protocol

\section{Helen Keller Content Analysis Tool}

1. Expected age/grade of the reader: primary (K-2), intermediate (3-5), middle level (6-8).

2. Genre: historical fiction, narrative non-fiction, expository, or graphic novel.

3. How did the author represent H. Keller's dispositions, attitude, motivation, and behavior?

4. How did the author represent A. Sullivan's dispositions, attitude, motivation, and behavior?

5. How did the author represent the emergent and ongoing relationship between Keller and Sullivan?

6. Did the author contextualize Keller's life in post-Reconstruction South? If yes, did the author include:

a. Keller family's socio-economic status

b. Racial tension (segregation, lynching, etc.)

c. Other significant events

7. Did the author describe Keller's life after the water pump revelation? If yes, did the author include:

a. Education: preparatory school, college, etc.

b. Involvement in entertainment industry: Vaudeville, movie, etc.

c. Generating money: books publishing, public speaking, etc.

d. Social activism: disability awareness/support, peace advocacy, suffrage movement, communism/socialism, internationalist causes

e. Other significant events

8. Did the author mention Keller's involvement with other famous historical figures? If yes, then list those historical figures.

\section{Rosa Parks Content Analysis Tool}

1. Expected age/grade of the reader: primary (K-2), intermediate (3-5), middle level (6-8).

2. Genre: historical fiction, narrative non-fiction, expository, or graphic novel.

3. Did the author mention or describe R. Parks's involvement in the NAACP, desegregation activities, or the civil rights movement prior to December 1, 1955?

4. How did the author characterize the start of segregation? As something that:

a. White America (citizens \& lawmakers) established and maintained

b. Seemingly had no source or system of preservation

5. When describing segregation, did the author mention that segregation had various elements:

a. Social segregation (separate schools, separate drinking fountains, separate restaurants)

b. Political segregation (i.e., voting restrictions for African Americans)

c. Economic segregation (i.e. limited job prospects for African Americans, sharecropping, lower pay for equal work for African Americans)

6. When describing Parks's refusal to give up her seat on December 1, 1955, did the author 
include other related events:

a. Supreme Court's decision on Brown v. Board of Education in 1954

b. The Emmett Till murder in August 1955

c. Claudette Colvin's spring 1955 arrest in Montgomery Alabama for refusing to give up her bus seat

d. Jo Ann Robinson's and The Women's Political Council's (of Montgomery Alabama) attempt to seek desegregated bussing in summer 1955

e. Other preceding events

7. When describing what happened after Parks's act of civil disobedience on December 1, 1955, did the author note that:

a. Tens of thousands took part in the yearlong Montgomery Bus Boycott

b. Violence, threats of violence, and being fired compelled Parks to move north

c. The Civil Rights movement would continue to gain strength for over a decade

d. Other subsequent events

\section{Eleanor Roosevelt Content Analysis Tool}

1. Expected age/grade of the reader: primary (K-2), intermediate (3-5), middle level (6-8).

2. Genre: historical fiction, narrative non-fiction, expository, or graphic novel.

3. How did the author represent E. Roosevelt's dispositions, attitude, motivation, and behavior?

4. How did the author characterize E. Roosevelt's mother, her mother's treatment of E. Roosevelt, and her mother's death?

5. How did the author characterize E. Roosevelt's father, her father's treatment of E. Roosevelt, his alcoholism, his involvement with a female servant, his death?

6. Did the author contextualize the Victorian norms that likely influenced E. Roosevelt's actions and beliefs about gender, family, and home life? If yes, then how?

7. Did the author contextualize the palpable and powerful difference between the poor and members of Society?

8. What did the author describe as the origins of E. Roosevelt's interest in social activism?

9. Did the author contextualize early to mid- $20^{\text {th }}$ century popular sentiment about race/ethnicity with specific events related to race/ethnicity like:

a. Jewish: Anti-Semitism, FDR's refusal to admit Jewish refugees

b. Asian: Strict immigration quotas, Japanese-American Internment

c. African-American: Segregation/Jim Crow \& lynching

10. When contextualizing E. Roosevelt's social activism, did the author denote her involvement with:

a. Women: Women's suffrage, right to work, etc.

b. Poverty/Unions: Child labor, labor unions, etc.

c. Race/ethnicity: civil rights, desegregation, anti-lynching, etc.

d. Military: Bonus Army marchers, treatment of injured veterans, etc.

11. How did the author characterize E. Roosevelt's relationship with Sara Roosevelt?

12. Did the author characterize E. Roosevelt's awareness of FDR's relationship with Lucy Mercer? If so, then how?

13. How did the author characterize E. Roosevelt's relationship with Earl Miller and female companions? 


\section{Findings}

This section reports empirical findings on each historical figure separately. Historians' understandings of each historical figure are juxtaposed with children's authors' historical representations. In doing so, we demonstrate the areas of divergence and convergence between historians and children's authors. We also illustrate the emergent patterns of historical representation and misrepresentation.

\section{Helen Keller}

The historicity of reviewed children's trade books on Helen Keller indicated considerable discrepancies from historical works. The children's narratives decontextualized Keller's early life events from the society in which they occurred and also omitted significant accomplishments in Keller's later life. While some differences in the amount and details of proffered information are expected when comparing history-based literature for children to history books for adults, these departures are consequential.

\section{The context of Keller's early life.}

The reviewed children's literature provided scant context about Keller's early life save geography and date. Historically relevant contextual variables included: demography and its impact on the resources available for Keller; technology and its impact on the popularization of Keller's story; and the tenuous nature of 19th century America and its impact on Keller's response to those marginalized from society. All three variables were noticeably omitted or significantly minimized within the children's literature.

Historian and Keller biographer, Dorothy Herrmann, characterized Keller's family as a "conventional southern family" (1998, p. 203). While not Vanderbilts or Rockefellers, the Kellers were rich in land, family name, and family history (Keller, 1929). Her father, Captain Arthur Henley Keller had a rich Confederate history, and effectively supported the family by working as both a newspaper editorialist and a "gentleman farmer" (Herrmann, p. 204). The demographic triumvirate of majority race, ethnicity, and religion coupled with Captain Keller's military and occupational connections both ensured a degree of security and, at times, bestowed influence (Nielsen, 2010).

While not a defense against sickness and disease, the security and influence enabled Keller's family to employ various Southern professionals to attempt to treat or cure Helen, stricken at the age of 19 months old from what modern doctors presume was either scarlet fever or meningitis (Herrmann, 1998). The security and influence provided Mrs. Kate Keller, Helen's mother, the compulsory time to locate and communicate with Northern professionals trainedhowever primitively by modern standards - to educate and socialize young Helen (Nielsen, 2010). While Keller was born to a woman who churned her own butter and a father navigating the tumultuous postbellum period, Keller had far more medical, educational, and social opportunities than a poor White child born to a family struggling for upward mobility or a poor African American child, free in name but fearful of lynching and starvation (Herrmann; Keller, 1929).

The narratives of all but two books $(n=13)$ disregarded the security and influence that Keller's family enjoyed (Kent, 2004; Lawlor, 2001). Narratives mentioning the Keller's socioeconomic status did so through allusion. The book, Helen Keller: Rebellious Spirit, noted the Kellers "spared no expense taking her [Helen] to every doctor they could find for treatments" (Lawlor, p. 18) and the Kellers possessed "financial resources" (p. 109). The children's 
literature either disregarded or indirectly mentioned to the Keller's family finances and its impact on Helen's life; this made the resultant and lifelong support from others appear to be present for anyone (rich or poor) motivated to search for help. If the teacher did not purposefully supplement such a narrative, the young reader would likely infer those who did not obtain help were unmotivated to seek such help. Such an inference is not historically accurate; Helen Keller was lucky to have such support, which consequentially impacted her life.

The history-based children's literature did not contextualize the media and inventions that popularized Keller's story. All the reviewed narratives $(n=15)$ mentioned Alexander Graham Bell's influence on the emergence of the telephone and his connection to Keller; not one children's book contextualized how new technologies like the telephone, printing press, and telegraph — at this instant prominent and inexpensive - more effectively and efficiently sped newsworthy information across an emerging country (Einhorn, 1998; Herrmann, 1998; Waite, 1959). In doing so, not one book within the random sample noted the attention Keller received, while clearly noteworthy, was contextually contingent to the historical period. If born even a quarter-century earlier and given a similar "miracle worker" teacher, the emergent media's celebration of Keller would not have been so instantaneous and intense. All of the history-based trade books disregarded the media-cultivated public persona for Keller save Helen Keller: Rebellious Spirit (Lawlor, 2001). If the teacher were to not enhance the narrative with additional content, the young reader would likely ascribe Keller's publicity entirely to Keller.

The children's books' narratives ignored the unstable and insecure life of late 19th century Americans. Whether urban or rural, poor White Americans worked menial jobs with little pay, no job security, and high risk of injury (Bodnar, 1985). They did not have access to (or time for) affordable education so there was little to no potential for upward mobility (Thernstrom, 1964). They had low life expectancy and high rates of disease and disability due to scant access to affordable medical treatment (Bodnar; Thernstrom). African Americans confronted all of the aforementioned work, education, and poverty issues but also faced an actively racist America (Hunter, 1997; Levine, 1977). Scholars have characterized this period as the "nadir of race relations" (Loewen, 2010, p. 189; Logan, 1965, p. 79) and noted that American states in the old Confederacy, like Keller's Alabama, were especially violent (Loewen). Keller, with firsthand experience of the helpless feelings derived from marginalization, was especially sensitive to those afflicted by disease, disability, and poverty. While every book noted Keller's early life, not a single book historicized the racial turbulence and economic disparities. Primarylevel books, for example, provided scant meaningful context like, "The year was 1880. Way down south in a little town in Alabama, a healthy baby girl was born" (Lundell, 1995, p. 2); intermediate-level books proffered little more additional content other than itemizing the farmproduced crops and farm-owned animals (Dubois, 2003); middle level books described "a large household staffed by many black servants" but gave no explanation of historical significance (Lawlor, 2001, p. 10). Keller's social consciousness, a key element in her adult life, was rooted in a landscape interwoven with class and racial strife. Young readers, perhaps, would miss important corollaries to race and social class if they relied only on the trade books.

The narratives of children's books about Keller were sated with the historical misrepresentations of exceptionalism, heroification, omission, and presentism. Exceptionalism and heroification manifested when children's books celebrated the successes as exclusive to 
Keller's resiliency and Sullivan Macy's diligence. Omission surfaced as the books disregarded the socioeconomic and demographic forces that literally paid Sullivan Macy's salary and both facilitated and rewarded Keller's resiliency. The catalysts for Keller's social conscience, which she herself characterized as a manifestation of her religiosity, were similarly omitted (Keller, 1927, 1929). The prominent and cost-efficient media-based technologies that sensationalized Keller's story were disregarded. These omissions facilitated presentism as the (young) reader likely fails to realize how such variables coalesced to foster Keller's social and educational development and contributed significantly to her place in popular culture. Since the foundational variables were not explored in the trade books, Keller's success seemed foreordained to the young reader. These patterns of historical misrepresentation, especially omission, reemerged more significantly as children's books detailed Keller's later life.

\section{The missions (and omission) of Keller's later life.}

As a mission-driven 20th century American adult, Keller campaigned for more than the public's awareness of and tolerance for disabled Americans. "The welfare of each is bound up in the welfare of all" was a call to arms both for and by Keller (Keller, 1929, p. 340). While sensationalized for overcoming disabilities, Keller sought to eliminate what she perceived to be the source of disability: poverty. To eradicate poverty, Keller supported socialism; she viewed it as the best chance to establish comprehensive brotherhood, justice, peace, and democracy (Einhorn, 1998; Herrmann, 1998; Nielsen, 2010). Perceiving the Socialist Party to be too gradual, Keller became a card-carrying member of the Industrial Workers of the World (IWW), a radical union, and asserted revolution was more important than education (Einhorn). Such sentiment was not uncommon in early 20th century America as a million (male) voters supported a 1912 socialist presidential candidate and the ranks of radical unions, like the IWW, grew quicker than traditional unions, like the American Federation of Labor (Brommel, 1978; Salvatore, 2007). While military force, police brutality, President Hoover's FBI emissaries, and blurred lines of judicial restraint confronted radical sentiment throughout America, Keller remained largely unscathed. Keller's avoidance of regulation can be attributed, to some extent, to the positive unintended outcomes of a celebrity status derived from resiliency in the face of disability (Foner, 1967; Herrmann).

The vast majority $(n=11)$ of the reviewed children's literature either disregarded or significantly diminished Keller's advocacy for universal prosperity, international peace, social justice, and Machiavellian tactics. One-third $(n=5)$ of the books entirely ignored Keller's advocacy (Cline-Ransome, 2008; MacLeod, 2007; Miller, 2007; Sutcliffe, 2002; Thompson, $2003)$ and just over one-third $(n=6)$ mentioned only Keller's advocacy for the deaf and blind (Adler, 1990; Delano, 2008; Dubois, 2003; Garrett, 2013; Lakin, 2002; Lundell, 1995). Stated differently, only one-fourth $(n=4)$ of the books historically represented the central missions of Keller's adult life.

Ironically, Leslie Garrett's (2013) intermediate-level book, Helen Keller, did not include social activism beyond Keller's advocacy for awareness and support for those with disabilities, but Garrett's (2004) middle level book detailed Keller's socialism, pacifism, and opposition to capitalism. Considering the latter was published almost a decade before the former, the author certainly was aware of the historical content. The omission in the intermediate-level book appears dubious when reading her narrative for middle level students: "To Helen, socialism was about equality, peace, and education for all" (Garrett, p. 94). Intermediate students can likely 
comprehend such content. While that author's decision appears to be one of sanitization, far more flagrant misrepresentations manifested. In A Picture Book of Helen Keller, for instance, the author noted, "She [Keller] did many things well. But most of all, Helen Keller brought hope and love to millions of handicapped people" (Adler, 1990, p. 28). Helen Keller: The World in her Heart ignored Keller's lifelong missions and accomplishments by ending the narrative when she was a child (Cline-Ransome, 2008). Arguably an engaging end to a story, Keller herself would likely not perceive her accomplishments at age eight as the climax of her life, but young students reading only such trade books will. Historically misrepresentative trade books contribute to young readers' inaccurate impressions of Keller's missions in life.

Other books were more inclusive of content. Helen Keller: Her Life in Pictures mentioned her acceptance of extreme measures, like her support of "hunger strikes and smashing windows" by anti-war protesters (Sullivan, 2007, p. 10). When mentioning Keller's advocacy for the deaf, blind, and disabled, Deborah Kent (2004) included her devotion to world peace, the poor, women's rights, and civil rights along with her support for both socialist and internationalist causes. Helen Keller: Rebellious Spirit represented Keller's philosophies and religiosity (specifically, Swedenborg and Marxism, social activism, and pacifism) and causes she supported (women's suffrage, women's health, the IWW, violent tactics for resistance, civil rights, and the proletariat during the Russian Revolution) (Lawlor, 2001). The book also included activities Keller criticized (big business, child labor, and lynching) and Keller's frustration at being compartmentalized to discussions about disabilities and not social or political issues (Lawlor). Only Lawlor noted Keller's family's intentional steps to reinvent Keller's legacy upon her death by, among other things, having a socially conservative senator give the eulogy at her funeral that was not the Swedenborg-themed ceremony she had wanted. In doing so, Lawlor demonstrated the malleability of history for children. While Lawlor's inclusion of such historical content should be applauded, her book was anomalous.

The palpable omission of Keller's missions in three-fourths $(n=11)$ of children's books was significant. A comparable example of disregard for a historical figure's missions would be if the same percentage of books about Agnes Gonxha Bojaxhiu, later known as Mother Theresa, focused only on her life until age eight, disregarding all aspects of her adult accomplishments and missions (Greene, 2004). What seems to be either a comically unimaginable oversight or an egregious historical omission for the Blessed Teresa of Calcutta's legacy was typical for Keller. Some children's authors infantilized Keller, compelling her to remain a child at the water pump deriving meaning from Annie's outstretched hand. Other writers compartmentalized Keller, giving details about her adult accomplishments and sanitized versions of Keller's social activism bereft of Keller's politics and religiosity. The vast majority omitted consequential content yet, as the subsequent examples demonstrate, Keller was not the only historical figure vulnerable to such omission.

\section{Rosa Parks}

Children's authors by and large decontextualized and omitted significant aspects of Rosa Parks's life and historical involvement in ways similar to the omission, sanitization, and compartmentalization of Keller's life and her missions. The children's books accurately portrayed Parks's exhibition of civil disobedience on December 1, 1955 but little else. Nearly all books omitted significant 19th and early 20th century events that marginalized - and elicited resistance from-African Americans; they similarly disregarded White Americans' culpability in 
segregation's initiation and maintenance. Most books ignored significant details surrounding Parks's courageous and defiant act on December 1, 1955; disregarded important people who contributed mightily towards the bus boycott's instigation and continuation; and overlooked the corollaries to Parks's involvement that single day, both for the Civil Rights Movement and her individually. For purposes of clarity, this section is organized by events preceding and following that eventful day.

\section{December 1, 1955 and before.}

Historians do not describe Parks's refusal to surrender her bus seat without considering germane contextual details. These include but are not limited to, Reconstruction and the nadir of race relations, White hate organizations like the Ku Klux Klan and African American advocacy groups like the National Association for the Advancement of Colored People, de facto discrimination and de jure discrimination, court cases like Plessy v. Ferguson and Brown v. Board of Education, extraordinary acts of resistance from ordinary citizens like Jo Ann Robinson and Claudette Colvin, and unconcealed examples of violent manifestations of racism unrestrained by law and order like the Emmett Till lynching (Metress, 2002; Robinson \& Garrow, 1987; Romano \& Raiford, 2006; Theoharis, 2013). Some of these details occurred nearly a century before December 1955 , while others were separated by less than a year; some were singular events and others were recurrent; all were relevant and contributed to Parks's purposeful act of civil disobedience (Brinkley, 1999; Theoharis). Few were incorporated within the examined children's literature.

The majority of children's books did not contextualize Parks's single act on December 1, 1955 as part of a pattern of resistance; they did not situate the event as the next step in an ongoing struggle. As most books disregarded the consequential historical prologue, the young reader likely credits Parks as the driving force for change, not simply as a luminous spark generated from a long-burning fire. In fact, only two books $(n=2)$ made explicit historical connections to the other relevant events and historical patterns. One book detailed Brown $v$ Board, lynching, de jure discrimination, and de facto discrimination, but no other variables (Adler, 1993). Another historicized Brown v Board and Emmett Till's lynching, but nothing else (Giovanni, 2005). The historicity within these aforementioned books was anomalous as the vast majority ( $n=13$ ) had demonstrably troublesome lacunae. Back of the Bus (Reynolds, 2010), for instance, did not provide the young reader a single preceding event, giving literally no context for the swelling resistance prior to December 1, 1955. Nearly all books $(n=13)$ omitted Claudette Colvin's and others' arrests for defiance similar to Parks's as only two noted bus desegregation attempts that preceded Parks's arrest (Greenfield, 1995; Kittinger, 2010). None of the Parks's texts mentioned Jo Ann Robinson's efforts on behalf of the Women's Political Council of Montgomery (AL) to seek democratic, peaceful solutions in appealing to the mayor months prior to Parks's arrest. By disregarding significant and similar precursors, the children's literature failed to minimally, let alone properly, contextualize this act of civil disobedience. Due to such historical oversights within the children's literature, the young reader would likely perceive Parks to be the sole spark for the movement were the teacher to not intentionally intervene with more inclusive and representative content.

White America created and sustained a dubious multifaceted system of segregation that extended from Reconstruction (Theoharis, 2013). Through illustration of Parks's active resistance to discrimination, children's authors attempted to explore the 19th and 20th century 
marginalization of African Americans. While not explicit, all of the children's authors $(n=15)$ alluded to de jure segregation (social separation supported by law) or de facto segregation (a racial separation, not necessarily supported by law, but maintained through tradition). In doing so, the authors sought to contextualize the social, legal, and political marginalization of African Americans. While imprecise or limited, such contextualization attempts were likely intended to be done in age-appropriate ways. Historians, however, know this to be only a partial view, disregarding two key variables. These two key points could easily be included in the children's literature in age-appropriate ways.

First, this partial view omits economic marginalization and its profoundly negative impact (Brinkley, 1999; Theoharis, 2013). While non-admittance to a city pool or a certain restaurant might generate anger, such marginalization did not dehumanize like economic marginalization. Examples of economic marginalization include: prohibition against gaining employment in certain professions, being compelled to work low pay jobs without benefits, and having little or no job security or union advocacy (Robinson \& Garrow, 1987; Romano \& Raiford, 2006). Economic marginalization of African Americans initiated a seemingly permanent cycle of poverty for African Americans and bolstered the accumulated wealth and job security for White Americans (Bynum, 2010; Theoharis, 2013). As civil rights scholar William Jones (2013) meticulously detailed, economic concerns, not simply racial equality and social integration, were the focus of the March on Washington for Jobs and Freedom (emphasis added). Parks, and her like-minded contemporaries, confronted social segregation but viewed the elimination of economic marginalization as compulsory for America fulfilling its democratic ideals (Dyson, 2000; Marable, 2011; Theoharis, 2013). None of the randomly sampled texts about Parks addressed economic marginalization nor did any book contextualize how poverty generates poverty in perpetuity. Given the question "What did Parks hope to gain through this act of civil disobedience, a better seat or a better life?," most young readers would select the former because the latter was disregarded. Young children could likely understand economic marginalization.

Second, this partial view fails to identify those who created and upheld the multifaceted system of oppression Parks actively resisted. White America cultivated, maintained, and benefited from the system of segregation (Jones, 2013; Loewen, 2010; Theoharis, 2013). Parks, and her contemporaries, felt vulnerable and recognized White Americans' complicity with segregation and inequity in the name of tradition; they worried about the potential futility of an unsuccessful, seemingly unending struggle; they recognized equality, justice, and democracy were not inevitable (Bynum, 2010; Marable, 2011; Theoharis, 2013). Not a single children's book detailed how White Americans instituted, upheld, and profited from segregation laws. A small number of children's authors $(n=3)$, however, explicitly noted White Americans actively marginalized others (Adler, 1993; Edwards, 2005; Ringgold, 1999). These three books each identified regular White Americans' active participation in segregation and intimidation, the power of the Ku Klux Klan, and early 20th century (White) police's specious protection of African Americans (Adler; Edwards; Ringgold). Most narratives were not specific and employed vague or exculpatory language with sentences such as: "Members [of the NAACP] might be arrested, hurt, or even killed if people who opposed civil rights for African Americans caught them" (Linde, 2012, p. 8) or "white people and African American people were kept apart (Schaefer, 2002, p. 9)." Such language does not attribute blame where it was due. These 
excerpts were illustrative examples of the majority of books that overwhelmingly disregarded ( $n$ $=12$ ) mention of those who contributed to de jure and de facto segregation, including Parks' own children's book (Parks \& Haskins, 1997). All books omitted content about the creation of de jure and de facto segregation. Boycott Blues: How Rosa Parks Inspired a Nation, for example, used a storm as a literary metaphor for the racist laws White America maintained (Pinkney, 2008), but no mention about its origination. Without historicizing its origin, young readers will likely view it as destined when, in fact, it was cultivated. Young students can likely comprehend that it was not fated.

The children's books similarly dismissed Parks's active involvement in the burgeoning Civil Rights Movement and her extensive resistance to segregation prior to December 1, 1955. While surveyed Americans identified Parks more than any other American female historical figure (Wineburg, 2008; Wineburg \& Monte-Sano, 2008), their understandings of Parks are exceedingly sparse and superficial (Theoharis, 2013; Wineburg et al., 2011). Historians do not characterize Parks as a simple seamstress, who being tired from a long work day became unwilling to follow Southern custom, the driver's directions, and police orders (Theoharis). Her awareness and activism began with her grandfather, a Marcus Garvey supporter, and continued with the National Association for the Advancement of Colored People (NAACP). Parks had two decades of NAACP experience prior to December 1, 1955. She raised funds for the legal support of the Scottsboro boys; gained practical civil disobedience tactics from the Highlander Fold School; and was galvanized by the Emmett Till lynching just weeks upon returning from Highlander (Theoharis). Parks was not an observer, but an apprentice of and an active participant in the emergent Civil Rights Movement. She did not stumble into a confrontation; she purposefully provoked arrest when the opportunity arose (Romano \& Raiford, 2006; Theoharis). Only one children's book (7\%), Rosa's Bus: The Ride to Civil Rights, (Kittinger, 2010) provided such historical contextualization. A young reader will likely, and inaccurately, infer Parks prevailed after unintentionally aggravating some misguided bullies who had previously been unchecked because the overwhelming majority of children's books $(n=14)$ do not state otherwise.

The majority of children's books omitted consequential historical events that preceded Parks arrest. In doing so, various historical misrepresentations emerged. Exceptionalism and heroification manifested, and were entwined, as the books characterized Parks bravery as anomalous and largely disregarded others' contributions. Presentism manifested when the narratives compel the young reader to view segregation's eventual conclusion as inevitable. Omission emerged when blame for the origin and systematic nature of segregation was not attributed to White Americans, which went largely unnoticed in the narratives. Omission was also present as the historical, economic, social, and educational contexts were either disregarded or largely underdeveloped. Omission was the most visible historical misrepresentation and also contributed significantly to exceptionalism, heroification, and presentism.

\section{Beyond December 1, 1955.}

Parks's act of civil disobedience on December 1, 1955 was one of many in a pattern of active resistance, which included Colvin's arrest for similar defiance and Robinson's civic actions (Garrow, 1989; Robinson \& Garrow, 1987; Theoharis, 2013). A coalescence of religious and political organizations mobilized the African American community to first shun the bus system for a day; the Montgomery Bus Boycott expanded in size and extended over a year until 
the Supreme Court deemed the local law unconstitutional (Garrow; Theoharis; Romano \& Raiford, 2006). Parks's local and national contributions to the Civil Rights Movement and the reciprocal response, which included death threats and occupational dismissal, were palpable then but largely forgotten now (Theoharis). Parks valued radical Black Power advocates like Malcolm X, the Black Panthers, and Louis Farrakhan and she appreciated left-wing political issues like poverty and pacifism (Theoharis). The children's literature did not incorporate such content.

While every reviewed book characterized Parks's actions that day as historically consequential, the majority of children's books $(n=10)$ disregarded Parks' subsequent involvement in the Civil Rights Movement (Edwards, 2005; Giovanni, 2005; Greenfield, 1995; Kittinger, 2010; Levine, 2005; Pingry, 2007, 2008; Pinkney, 2008; Reynolds, 2010; Ringgold, 1999). Only five (33\%) reported Parks' political activity after her arrest in December of 1955 and those that did focused only on her activities in the mainstream Civil Rights Movement (Adler, 1993; Kellaher, 2007; Linde, 2012; Parks \& Haskins, 1997; Schaefer, 2002). Stated differently, the majority of books $(n=10)$ disregarded Parks's post-arrest political activity, and none of the books explored Parks's anti-poverty, anti-war, and Black Nationalist advocacy.

Historical omissions about precursors to Parks's December 1955 arrest (noted in the previous subsection) and her political activism after Parks's December 1955 arrest parallel the historical misrepresentations of the Montgomery Bus Boycott. The vast majority of children's books $(n=14)$ contextualized Parks' actions as the catalyst for something larger but failed to historicize the Montgomery Bus Boycott in four critical ways. First, nearly three-fourths ( $n=$ 11) did not note that the boycott was a substantive step forward for the burgeoning Civil Rights Movement (Edwards, 2005; Giovanni, 2005; Greenfield, 1995; Kittinger, 2010; Levine, 2005; Linde, 2012; Pingry, 2007, 2008; Pinkney, 2008; Reynolds, 2010; Schaefer, 2002). In perhaps the most comprehensive account, Jeanne Theoharis (2013) contextualized the Montgomery Bus Boycott as a midpoint in a decades-long social movement. When included in children's books, the boycott was explicitly characterized as the beginning of the movement and, in many, implicitly described as a decisive step.

Second, many children's books did not properly historicize those who started and sustained the Montgomery Bus Boycott. The children's books frequently $(n=11)$ credited both national and local civil rights leaders like Dr. Martin Luther King, Jr. and Edgar Daniel Nixon for initiating the boycott. They also credited average citizens for maintaining it. A considerable portion of books $(n=4)$, however, credited the leaders but failed to mention the diligence required by the average citizens to maintain the yearlong boycott (Pingry, 2007, 2008; Reynolds, 2010; Schaefer, 2002). The credit not given to the average boycotter was as noticeable as the credit not given to the female advocacy groups. A small number of books $(n=4)$ mentioned the efforts of the Women's Political Council of Montgomery (AL) or Jo Ann Robinson to initiate and maintain the boycott (Giovanni, 2005; Kellaher, 2007; Parks \& Haskins, 1997; Ringgold, 1999). Women and women's groups' contributions were critical but largely unnoticed by the male elite in much the same way poor citizens' involvement was significant but overlooked by the movement's bourgeois elite (Theoharis, 2013). Left to her own readings of the majority of the children's literature, a young reader would likely credit the male leaders, not the average citizen and not the women. 
Third, the majority of books $(n=8)$ did not describe any violence, threats of violence, and displays of power directed at boycotters (Edwards, 2005; Giovanni, 2005; Kittinger, 2010; Pingry, 2007, 2008; Pinkney, 2008; Reynolds, 2010; Schaefer, 2002). Of the seven (47\%) books that historically represented some turmoil, four (27\% of cumulative total) explicitly acknowledged the turmoil and three ( $20 \%$ of cumulative total) did so implicitly. An example of a narrative that proffered palpable details, comes from Karen Kelleher (2007):

The protest was especially hard for Rosa. She began to get phone calls from some angry whites. They blamed her for the 'trouble' she was causing. Some even threatened to kill her. Rosa and her husband both lost their jobs. She was even arrested again. This time for boycotting!" (p. 28)

Noteworthy details included the verbal harassment, threats of violence, subsequent arrest, and job dismissal. The young reader consumes tangible but non-graphic details of the turmoil. Educators and parents, however, might not deem certain content to be age-appropriate if explicitly conveyed, like vigilantes' bombings of churches (Adler, 1993; Ringgold, 1999, p. 18). Still, the boycott cannot be accurately told without mentioning some violence; they were inextricably intertwined. Other books, intending to incorporate historically accurate content, veiled the turmoil or only implicitly referenced it. The following excerpt provides an example: "Some white people wanted to stop the boycott. They didn't like black people standing up for themselves. They tried to scare Rosa and other black leaders, but the boycott went on" (Levine, 2005 , p. 23). The young reader is left to wonder exactly what "to scare" meant because scant details were provided. While disagreements could emerge over how best to address the violence in the children's books, almost three-quarters $(n=11)$ either omitted the turmoil or sanitized it through acknowledgement sans details. Such narratives either leave the reader unaware of the violence and threats of violence or leave the reader aware that something happened but unaware of its extent and nature.

Finally, the vast majority of books $(n=11)$ did not identify an aggressor in the violence and threats of violence aimed at those boycotting the Montgomery Busses. By omitting the turmoil entirely, the majority of authors $(n=8)$ did not pinpoint culpability on White America (Edwards, 2005; Giovanni, 2005; Kittinger, 2010; Pingry, 2007, 2008; Pinkney, 2008; Reynolds, 2010; Schaefer, 2002). Another sizeable group $(n=3)$ mentioned the turmoil but did not identify White Americans as the cause (Adler, 1993; Linde, 2012; Ringgold, 1999). An excerpt from Rosa Parks exemplifies this blameless description of the turmoil, "Members [of the NAACP] might be arrested, hurt, or even killed if people who opposed civil rights for African Americans caught them" (Linde, 2012, p. 8). Only four, or 27\% of cumulative total, children's authors identified White Americans as the aggressor (Greenfield, 1995; Kellaher, 2007; Levine, 2005; Parks \& Haskins, 1997). Nearly three-quarters $(n=11)$ of books either omitted or failed to identify White Americans as the initiators of the turmoil. The young reader, thus, is not cognizant of those who caused the turmoil.

The majority of the children's books misrepresented the historical context of the Montgomery Bus Boycott, the turmoil surrounding the yearlong boycott, and White citizens' active involvement. The books failed to properly credit female leadership and average boycotters' involvement in the Montgomery Bus Boycott. In doing so, the young reader credits Parks as the driving force for change, not simply a spark that contributed mightily to (but also arose from) a long-burning fire; the young reader is unable to appreciate those who persevered 
through the lengthy, dangerous boycott against a resistant White citizenry. That the majority of books reviewed displayed such patterns is regrettable and historically inaccurate, yet many single narratives displayed egregious historical misrepresentations. Their relatively anomalous nature made them no less concerning. The book, Back of the Bus (Reynolds, 2010) failed to include anything that came before or after the day of Parks' arrest. More details were provided about a little boy's marble than about the little boy witnessing someone's arrest. Since Back of the Bus provided no explicit connections, the young reader likely does not reflectively connect what the little boy witnessed, his marble, and historical change (Reynolds). Whereas Back of the Bus diminished the historical significance, If a Bus Could Talk egregiously embellished it:

"The buses were the worst form of segregation [emphasis added] because black people could only sit in the back of the bus. If there were no whites in the middle section blacks could sit there, but only if no white people were left standing. Black people couldn't sit in the same row with whites, even if there was an empty seat in that row" (Ringgold, 1999, p. 10).

Bus segregation was dehumanizing and should not be minimized, but it was far from the worst form of segregation. Every book characterized Parks's actions as historically consequential, but the findings indicate that few achieved historicity. Omission was most palpable as significant details and events were disregarded or went unused. Heroification and exceptionalism were both inextricably intertwined and were the resultant implications of such omission.

\section{Eleanor Roosevelt}

In stark contrast to Parks and Keller, children's authors contextualized and represented Eleanor Roosevelt with strong historicity. There was some divergence between historians' and children's authors' narratives, as would be expected due to the intended audience. It was meaningful, however, that both historians' and children's authors' narratives converged in agreement on the majority of the material. Roosevelt was collectively characterized as altruistic and concerned for those less fortunate; as diligently advocating for justice for those who were marginalized; and fiercely devoted to her family, even those members who would likely be judged by contemporary standards as undeserving of her devotion.

\section{Eleanor Roosevelt's altruism.}

Eleanor Roosevelt's altruism manifested in various ways throughout her life. As a child both during the holiday season and throughout the year, young Eleanor volunteered time in and donated tangible goods to New York City soup kitchens, hospitals, and ministries (Beasley, 2010; Hareven, 1968). Roosevelt (1961, p. 12-13) herself credited various family memberslike her grandmother, father, Uncle Vallie, Aunt Gracie, and countless others - for encouraging and enabling her initial participation. The Victorian notion of "noblesse oblige" compelled members of Society to outwardly demonstrate charity (Hareven, 1984, p. 202). Eleanor Roosevelt's altruism increased during her time at the private school Allenswood due, in part, to Mademoiselle Souvestre's influence. Upon her return, a teenage Eleanor reassumed previous volunteering activities with other Society young people who were compelled by a Victorian sense of duty; she also sought activities that such future Society matrons would not perform, like teaching in lower Manhattan (Beasley, 2010; Hareven, 1968; Roosevelt, 1961). Initiated by family and friends of Society, bolstered by Mademoiselle Souvestre, and maintained by her own 
willingness to follow an internal compass of compassion, scholars assert Roosevelt's altruism had many origins and many influences (O'Farrell, 2011).

All children's authors noted Eleanor Roosevelt's altruism but were historically misrepresentative in three ways. First, children's authors contextualized the onset of Eleanor Roosevelt's altruism more singularly. A majority of books $(n=9)$ noted a particular location for the genesis for Eleanor Roosevelt's social activism: four noted its genesis in New York City missions, hospitals, and soup kitchens when she was a child (Cooney, 1996; El Nabli, 2006; Feinberg, 2003; Fleming, 2005); three noted Allenswood (Santow, 1999; Vercelli, 1995; Winner, 2004); and two depicted Washington-area veterans' hospitals as she buttressed Franklin Roosevelt's appointment as secretary of the navy during the Great War (Ellwood, 1999; Koestler-Grack, 2004). The remaining books $(n=6)$ contextualized Eleanor Roosevelt's social activism as having two specific origins: five contextualized her altruism as starting in adulthood in New York City and continuing during her role as first lady (Adler, 1991; Freedman, 1993; Kulling, 1999; Rappaport, 2009), and one noted her childhood visits to New York City hospitals and while witnessing poverty on childhood vacation in Italy (Thompson, 2004). As mentioned, historians characterize all experiences as contributory to her demonstrable and lifelong altruism. The children's authors, however, arbitrarily designate where and when Eleanor Roosevelt's social activism began, which leaves an incomplete narrative for the young reader.

Second, and similar to how children's authors noted singular events as the origin of Eleanor Roosevelt's altruism, the majority of children's authors $(n=8)$ recognized only one or two people as catalysts to her demonstrable and lasting altruism. Credit was given to Eleanor Roosevelt's uncle, President Theodore Roosevelt (Fleming, 2005), her father, Uncle Vallie (Cooney, 1996; El Nabli, 2006; Thompson, 2004), her grandmother Hall (Feinberg, 2003), or her Allenswood teacher, Mademoiselle Souvestre (Santow, 1999; Vercelli, 1995; Winner, 2004). Historians assert that all the aforementioned people - and many more that did not make the above list - contributed to Eleanor Roosevelt's altruism. A near-similar number of children's authors $(n=7)$ focused on events and experiences and omitted recognition of those who contributed to her philanthropy. Since the children's books are unduly singular, a young reader digesting any one of the reviewed books may not understand that all of the aforementioned people contributed to Eleanor Roosevelt's social activism albeit in different ways and at different times.

Finally, none of the reviewed trade books contextualized the Victorian norms of late 19th century that compelled members of Society into service. Historians recognize Eleanor Roosevelt's family and Society friends gave and sought publicity for their giving due, in part, to their adherence to the Victorian noblesse oblige (Beasley, 2010; Hareven, 1968, 1984). The children's authors' non-contextualization of Victorian America leaves a young reader unable to make such connections.

All three historical misrepresentations are rooted in exceptionalism, omission, and presentism. Particular people and definitive experiences are credited as catalysts for Roosevelt's extraordinary and lifelong philanthropy. The root of such singularity is exceptionalism and omission of other content. Such omission can be understood, if not excused, if it was the authors' purposeful attempt to avoid inundating young readers with superfluous information (Collins and Graham, 2001; Graham, 2001). It is, however, the author's responsibility to construct a historically representative narrative that children find comprehensible and engaging. 
Children's authors historically contextualized far more complicated and esoteric content than Victorian America. A young reader will not independently detect the influence of Victorian norms. Instead, the young reader will likely unintentionally engage in presentism by ascribing 21 st century perspectives and understandings onto 19th century behaviors and attitudes. The omission of content about Victorian society was intentional and palpable, much like the pattern of singularity in this subsection's first two historical misrepresentations.

\section{Eleanor Roosevelt's diligent pursuit of justice.}

Eleanor Roosevelt purposefully and intensely worked towards establishing impartial and just treatment for all. She confronted social, political, or economic regulations that marginalized people by race, ethnicity, gender, socioeconomic status, country of origin, or health (Ware, 1984; Zangrando \& Zangrando, 1984). Whether as a private citizen, political spouse, editorialist, or international humanitarian, Eleanor Roosevelt followed and modeled the ideals of peace and justice (Cook, 1992, 1999; Goodwin, 1995). In the United States, she sought to eliminate, diminish, or at least criticize boundaries she perceived to be incoherent with American democracy regardless of the popular sentiment. Roosevelt's support for "seemingly contradictory causes bewildered her contemporaries and left even her supporters feeling that her activities had no coherent pattern" (Hareven, 1984, p. 201). In the international arena, she worked to compel world leaders, American and foreign, to act in the best interest of humankind. Eleanor Roosevelt advocated for the ideals of both the United Nations and the Universal Declaration of Human Rights, a document she contributed to mightily (Beasley, 2010; Cook, 1992). Roosevelt's international activism after her husband's death garnered at least as much attention_-positive and negative—as her domestic activism (Black, 1996; Cook, 1984).

Every children's book $(n=15)$ included in this study recognized both Eleanor Roosevelt's international diplomatic activism and two of her domestic social issues: women's right to vote and African American's civil rights. While it was meaningful that so many books explicitly acknowledged Eleanor Roosevelt's global activism and domestic support for women's rights and civil rights, it was also expected considering her activism was distinguished and substantive. The children's authors, however, disregarded many causes she championed. Only three noted her resistance to President Roosevelt's internment of Japanese-Americans (Feinberg, 2003; Fleming, 2005; Rappaport, 2009); just two recognized her opposition to lynching (Feinberg, 2003; Vercelli, 1995); less than half $(n=6)$ recognized her activism to end child labor and support labor unions (Adler, 1991; DeYoung, 1999; Ellwood, 1999; Feinberg, 2003; Santow, 1999; Winner, 2004); and only two addressed her resistance to America's xenophobia, antiSemitism, and unwillingness to admit European refugees during World War II (Feinberg, 2003; Rappaport, 2009). While Eleanor Roosevelt's advocacy for certain interests ebbed and flowed, her awareness of labor issues never diminished with time (Cook, 1992, 1999; O'Farrell, 2011). Young readers, thus, become aware that Eleanor Roosevelt was an advocate but have an incomplete awareness of which causes she supported.

It would be unreasonable to expect every children's book to explore every social and domestic issue that Eleanor Roosevelt championed, yet the most commonly recognized issues in the children's books - women's rights and civil rights - were those in least dispute in contemporary American society. It seems likely Eleanor Roosevelt's social activism in unmentioned areas potentially casts unwanted and negative light today. Contemporary discussion about Japanese-American Internment places President Roosevelt in a poor light; child 
labor indicts business owners in analogous ways to how lynching indicts White Americans; labor unions remain politically sensitive; and America's war time xenophobia, anti-Semitism, and denial of refugees summon harsh critique from international circles. These, however, were causes that Eleanor Roosevelt championed and valued. The vast majority of children's authors $(n=12)$ either ignored entirely or significantly minimized her involvement in these seemingly sensitive causes. Six books disregarded Eleanor Roosevelt's involvement in all four causes (Cooney, 1996; El Nabli, 2006; Freedman, 1993; Koestler-Grack, 2005; Kulling, 1999; Thompson, 2004). Another six recognized her activism for just one seemingly sensitive cause (Adler, 1991, DeYoung, 1999; Ellwood, 1999; Santow, 1999; Vercelli, 1995; Winner, 2004). Three authors were more historically representative as two mentioned two sensitive causes (Fleming, 2005; Rappaport, 2009) and one incorporated all four (Feinberg, 2003). The intended audience for these books-Eleanor: Quiet No More (Rapport, 2009) was written for primary readers, Eleanor Roosevelt (Feinberg, 2003) for intermediate elementary students, and Our Eleanor (Fleming, 2005) for middle level children - indicates children's authors can incorporate and adapt politically sensitive issues for a variety of reading abilities.

To explain why all children's authors included Eleanor Roosevelt's support of women's rights and civil rights but most did not acknowledge her social activism in other areas is speculative at best. It appears that authors engaged in deliberate self-censorship of potentially contentious material, which is an arguably prudent choice considering these trade books are commercial, not historical, texts. Research indicates textbooks (Chick, 2006; Loewen, 1995; Matusevich, 2006) engage in expurgation. Omission, a form of historical misrepresentation, is ubiquitous in trade books on certain topics but the field is largely unexamined (Bickford, 2013a; Williams, 2009). A significant majority of children's authors $(n=12)$ either disregarded or drastically minimized Eleanor Roosevelt's involvement in causes that appear politically sensitive or contentious today. While omission was clearly present, the reason for its frequency remains unclear.

The above discussion about Eleanor Roosevelt's activism for justice in international and domestic issues centered on if, not how, they were included in the children's literature. Children's books' descriptions of her involvement with the Bonus Army, however, deserve examination of how it was characterized. The Bonus Army was comprised of unemployed veterans of the Great War, and their families, seeking the government's compensation of a bonus they were promised. During the end of Herbert Hoover's presidency, they marched at the capital, camped nearby, sought constructive dialogue with the White House, and (fruitlessly) lobbied Congress to pass legislation ensuring their bonus (Beasley, 2010; Scharf, 1987). President Hoover resented the media attention, refused dialogue, and ordered their dispersion. When they would not, a Hoover-ordered U.S. military eviction quickly evolved into a massacre, characterized as "state terrorism" by one historian (Cook, 1999, p. 45). After President Roosevelt's election, the Bonus Army returned to obtain the bonus and protest reduction of benefits. President Roosevelt provided clean campsites, maintained sanitation facilities, and solicited dialogue with the veterans but he would not pay the bonus (Beasley; Scharf). After discussions with and encouragement from Louis Howe, a close advisor to the president, Eleanor Roosevelt chose to visit the campsite, sang songs with the veterans, and shared her wishes that their requests would receive reasonable consideration and peace be perpetual so no more soldiers are needed (Cook). With spirits cheered from her attention and consideration, the veterans 
eventually left the capital without the bonus but with renewed respect for Eleanor Roosevelt, President Roosevelt, and the administration (Beasley; Cook; Scharf). Eleanor Roosevelt herself (1961) reflected she appreciated Howe's encouragement and wished she could have done more, but acknowledged the political realities her husband faced.

Children's books characterize the events quite differently. The vast majority of the books $(n=12)$ ignored Eleanor Roosevelt's involvement with the Bonus Marchers. Three children's books $(20 \%)$ incorporated it, but differed significantly in two distinct ways. First, all three characterized the catalyst for her involvement quite differently. One attributed Eleanor Roosevelt's visit to the Bonus Army as President Roosevelt's prudent political decision (Winner, 2004); another credited Eleanor Roosevelt for being curious and compassionate (Freedman, 1993); still another recognized Louis Howe for the sensible decision to engage Eleanor Roosevelt in this issue (Fleming, 2005). Each author thus credited a different source for her involvement. Second, the authors described the context Eleanor Roosevelt walked into quite differently. While two children's authors characterized the inhabitants of the encampment as quiet but determined (Fleming; Freedman), one noted that Eleanor Roosevelt "went into the middle of the violent protesters to discuss their grievances" (Winner, p. 29). A young student reading any number of these books would be either completely unaware or incompletely aware of Eleanor Roosevelt's connection to the Bonus Army.

The example of Eleanor Roosevelt and the Bonus Army has great value for the classroom, which will be detailed in the subsequent section. As it relates to this section and the Bonus Army, the vast majority of narratives $(n=12)$ omitted this event. A small minority incorporated her concern for the Bonus Army $(n=3)$ within their narratives, yet the stories told were significantly different. One engaged in heroification by exaggerating the context Eleanor Roosevelt entered (Winner, 2004) and two achieved historicity (Fleming, 2005; Freedman, 1993). The former implied almost a riot; the latter two were more precise in describing a tranquil but serious context. The pattern of omission, as noted in other areas above, emerged here. Presentism, exceptionalism, and heroification were largely absent from Eleanor Rooseveltbased children's literature as it related to her social activism and diligent pursuit of justice.

\section{Eleanor Roosevelt's devotion to family.}

Eleanor Roosevelt resiliently faced and rose above familial turmoil and conflicts. She adored her father, Elliot, a man of unsavory character. He was known as a sometimes violent alcoholic, a philanderer who possessed an illegitimate child, an estranged father who would bestow few encouraging words, and a man whose poor choices contributed consequentially to a premature death at 34 years of age (Cook, 1992; Scharf, 1987). Eleanor Roosevelt's mother, Anna, was beautiful and envied but quite was embarrassed of "Eleanor's homely appearance" and shy, introverted disposition (Cook, 1992; Hareven, 1968, p. 2). Her mother-in-law, Sara Roosevelt, was meddlesome and expressed dissatisfaction frequently with Eleanor Roosevelt's actions as mother, wife, and activist; yet, Sara Roosevelt exhibited great devotion and tenderness towards Eleanor Roosevelt (Pottker, 2005).

Eleanor Roosevelt's husband, Franklin, had an extensive affair with Lucy Mercer (later Rutherford), a secretary that Eleanor Roosevelt initially hired. Franklin Roosevelt's marital transgressions were recognized and, at times, both accepted and supported by, among others, Eleanor Roosevelt's cousin Alice and daughter Anna (Pottker, 2005; Scharf, 1987). Whether these were viewed individually or cumulatively, few would condemn Eleanor Roosevelt for 
either the natural and expected emotions she likely initially felt or the feelings that certainly reemerged later upon reflection (Cook, 1999; Pottker). Friends and scholars alike credit her poise and devotion to family as she excused others' seemingly inexcusable choices (Lash, 1964; Pottker; Scharf). While historians cannot discern the details of confidential late night spousal discussions nor detect Eleanor Roosevelt's inner thoughts, history confirms she defended and protected her family in words and deeds even if she did not forget the lapses (Cook, 1992, 1999; Pottker). In her autobiography, Eleanor Roosevelt (1961) omitted or drastically minimized all of the aforementioned and, in doing so, demonstrated praiseworthy familial fidelity.

Children's authors characterized Eleanor Roosevelt's family devotion and family members' various transgressions quite similarly to historians. Every trade book included in the random sample noted her lonely and cheerless childhood, her parents' early deaths, her father's struggles, and her mother-in-law's dominating personality. Considering the intended audience was elementary school students, these were all age-appropriate familial issues to recognize. Other topics might be deemed unsuitable for youngsters. For instance, most of the books ( $n=$ 12) either explicitly recognized or implied the infidelity; only three disregarded it (El Nabli, 2006; Ellwood, 1999; Koestler-Grack, 2004). While all books, within the random sample, mentioned her father, Elliot, died young, the majority $(n=11)$ did not detail how he died. Those books that did provide details differed dramatically as one termed it a suicide (Fleming, 2005), two noted a fall (Cooney, 1996, p. 18; Koestler-Grack, p. 9), and one characterized it as alcohol poisoning (Feinberg, 2003, p. 8). One book explicitly noted that her father, Elliot, impregnated a female servant (Vercelli, 1995) and another implied it (Fleming, 2005); the majority of books ( $n$ $=13$ ) disregarded this situation. Considering the sensitivities of young readers, it would be questionable to expect all of the books to incorporate all of the aforementioned content. It was dubious, however, that not a single one of the reviewed books explicitly contextualized the expectations for a mother and wife of Victorian and socially elite Society. Various authors implied Victorian sensibilities with statements such as the following: "Eleanor was a good wife for a politician. She knew when to ask questions and when to keep quiet" (Rappaport, 2009, p. 14 ) and "I can only say that my one great wish is always to prove worthy of him" (Vercelli, p. 34). Lack of explicit historical contextualization, however, compels the young, unaware reader to place the onus for her deference and forgiveness of family members on Eleanor herself. Eleanor Roosevelt can and should be credited for the absolution she gave, but if it is not contextualized, then the young reader might mischaracterize her as a figurative doormat. She was no doormat; she earned the respect and admiration from family, friends, and people worldwide for her integrity, not acquiescence (Lash, 1964; Pottker, 2005).

Similar to the previous section examining her social activism, three historical misrepresentations - presentism, exceptionalism, and heroification-were largely absent as omission manifested. This omission related to both the events and people who wronged her but also the Victorian norms that compelled her to forgive and, at least publically, ignore the injury and harm done. Historical misrepresentations in these children's books were similar in number but minor in intensity when compared to narratives about Parks and Keller. The Eleanor Roosevelt-based children's literature largely achieved historicity.

\section{Advancing the Use of History-Based Children's Literature}

Comprehensive historical representation cannot be derived from a single textbook, a lone primary historical source, or any one particular history-based children's book. From the 
participant's retelling to the eyewitness's recalling to the historian's writing, bias and perspective pervades all primary accounts and secondary narratives. Bias, as an intellectual construct, includes the corollaries of intent, (un)awareness of pertinent information, and partiality (Bickford, 2013b; Wineburg, 2001). Perspective, as an intellectual construct, is based on evidence acknowledged and evidence disregarded (Bickford, 2013b; Nokes, 2011). The ubiquity of bias and perspective compels teachers to direct students towards the examination of authorial choices. Given that secondary historical texts' length and complexity are beyond the reach of elementary students and that historians generate divergent accounts resplendent with nuances beyond their grasp, teachers should utilize history-based children's literature as a proxy (Bickford, 2013b). Engaging, age-appropriate, but conflicting children's narratives provide students the opportunity to grapple with the evidence and arguments that compelled the historical accounts to diverge. Students' historical thinking is further complicated, and corroborated, through examination of relevant (and modified) primary source material (Bickford, 2013b; Nokes, 2011; Wineburg, 2001). Elementary students can thus actively assemble understandings derived from readings of multiple and varied primary and secondary historical sources, which form the basis for the first nine Common Core elementary reading standards for informational texts (CCSSI, 2010). For illustrative purposes, we demonstrate first how primary sources can supplement one area where narratives diverge. We then proffer primary sources intended to address the various historical omissions replete within the narratives.

\section{Eleanor Roosevelt and the Bonus Army}

The children's narratives diverge significantly in if, and how, they characterized Eleanor Roosevelt's interactions with the Bonus Marchers. Twelve books omitted this event entirely from their narrative. Three books included it but had divergent characterizations of who initiated the interaction and the context of protest. One author credited Eleanor Roosevelt's involvement to her own curiosity (Freedman, 1993), another attributed her involvement to her husband's shrewd political prudency (Winner, 2004), and a final writer recognized President Roosevelt's political advisor as the catalyst for her involvement (Fleming, 2005). As noted above, one book described Eleanor Roosevelt as in "the middle of the violent protesters" in an attempt "to discuss their grievances" (Winner, p. 29) whereas two other books characterized the crowd as quiet but determined (Freedman; Fleming).

State and national initiatives, beginning in the primary grades and spiraling through high school, expects students to discern context-specific language, distinguish authorial bias and perspective, and juxtapose competing first- and second-hand accounts of the same event (CCSSI, 2010; CCSSO, 2012; NCSS, 2013). The above children's literature with disparate accounts will likely elicit students' queries about accuracy, which provides space for the inclusion of primary source material. In order to complicate students' understandings of both the event and the contradictory accounts of the event (and, in doing so, meet the rigorous standards), the teacher can have students juxtapose multiple children's books and analyze illustrative (and modified) primary accounts like those that follow. 
... I shall never forget my feeling of horror when I learned that the Army had actually been ordered to evict the veterans from their encampment. In the chaos that followed, the veterans' camp ... was burned and many people were injured, some of them seriously.

When the second bonus march took place in March of 1933 I was greatly worried for fear nothing would prevent a similar tragedy. However, after talking the situation over with Louis Howe, Franklin immediately decided that the veterans should be housed in an old camp and provided with food through the relief administration. Louis spent hours talking with the leaders. I think they held their meetings in a government auditorium and were heard by the proper people in Congress. As a result, everything was orderly.

Although Louis often asked me to take him for a drive in the afternoon, I was rather surprised one day when he insisted that I drive him out to the veterans' camp... When we arrived he announced that he was going to sit in the car but that I was to walk around among the veterans and see just how things were. Hesitatingly I got out and walked over to where I saw a line-up of men waiting for food. They looked at me curiously and one of them asked my name and what I wanted. When I said I just wanted to see how they were getting on, they asked me to join them.

After their bowls were filled with food, I followed them into the big eating hall. I was invited to say a few words to them - I think I mentioned having gone over the battlefronts in 1919 - and then they sang for me some old army songs. After lunch I was asked to look into several other buildings, and finally we came to the hospital that had been set up for them. I did not spend as much as an hour there; then I got into the car and drove away. Everyone waved and I called, "Good luck," and they answered, "Good-by and good luck to you." There had been no excitement, and my only protection had been a weary gentleman, Louis Howe...

Figure 1. $\quad$ Roosevelt, E. (1961). The Autobiography of Eleanor Roosevelt. New York, NY: Harper \& Brothers Publishers, pages 175-176. 
Social Studies Research and Practice www.socstrp.org

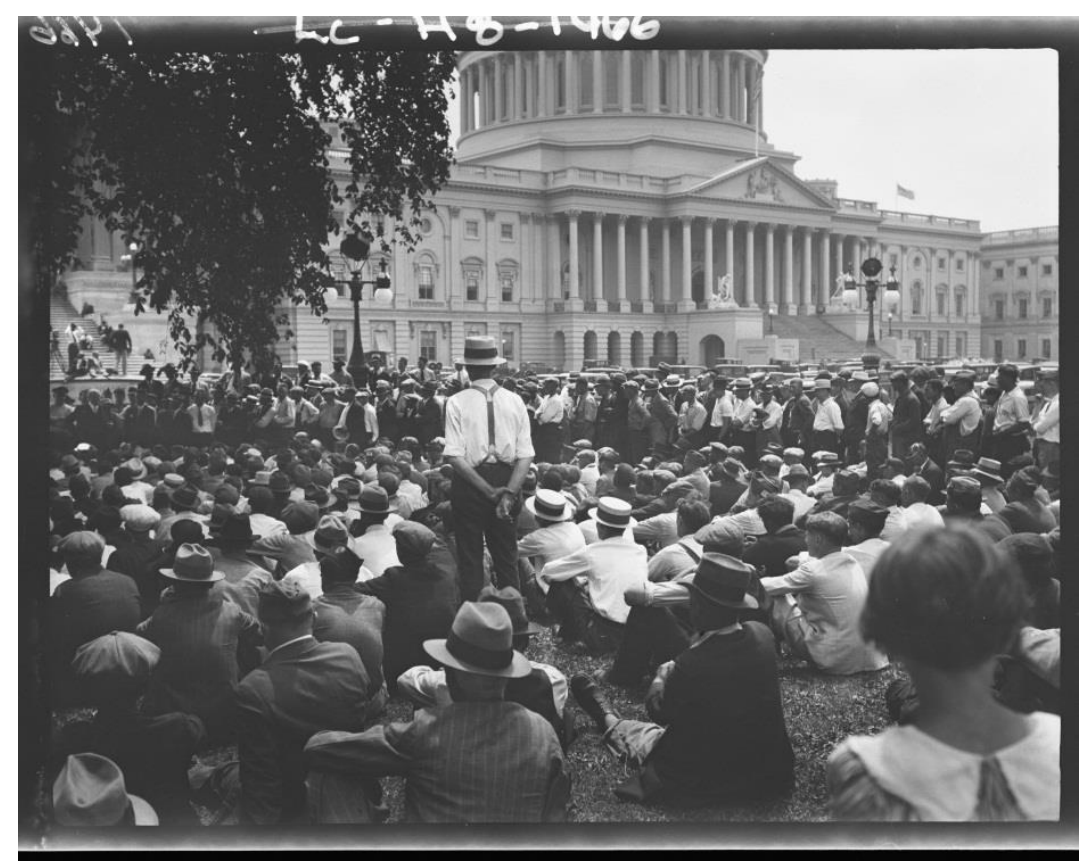

Figure 2. Horydczak, Theodor. (ca. 1920-1950). Bonus veterans. B.E.F. at the U.S. Capitol. Prints and Photographs Theodor Horydczak Collection. Library of Congress.

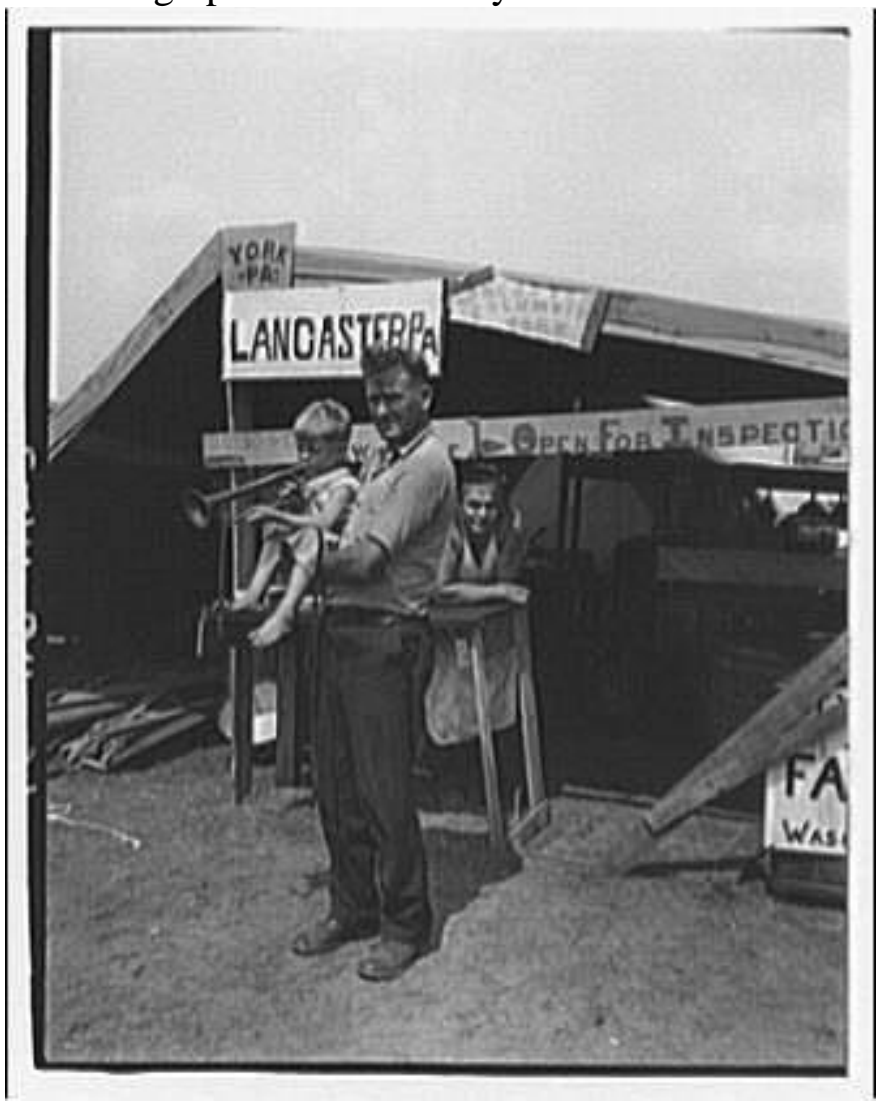


Figure 3. Horydczak, Theodor. (ca. 1920-1950). Bonus veterans. Kid from York, Pennsylvania. Prints and Photographs Theodor Horydczak Collection. Library of Congress.

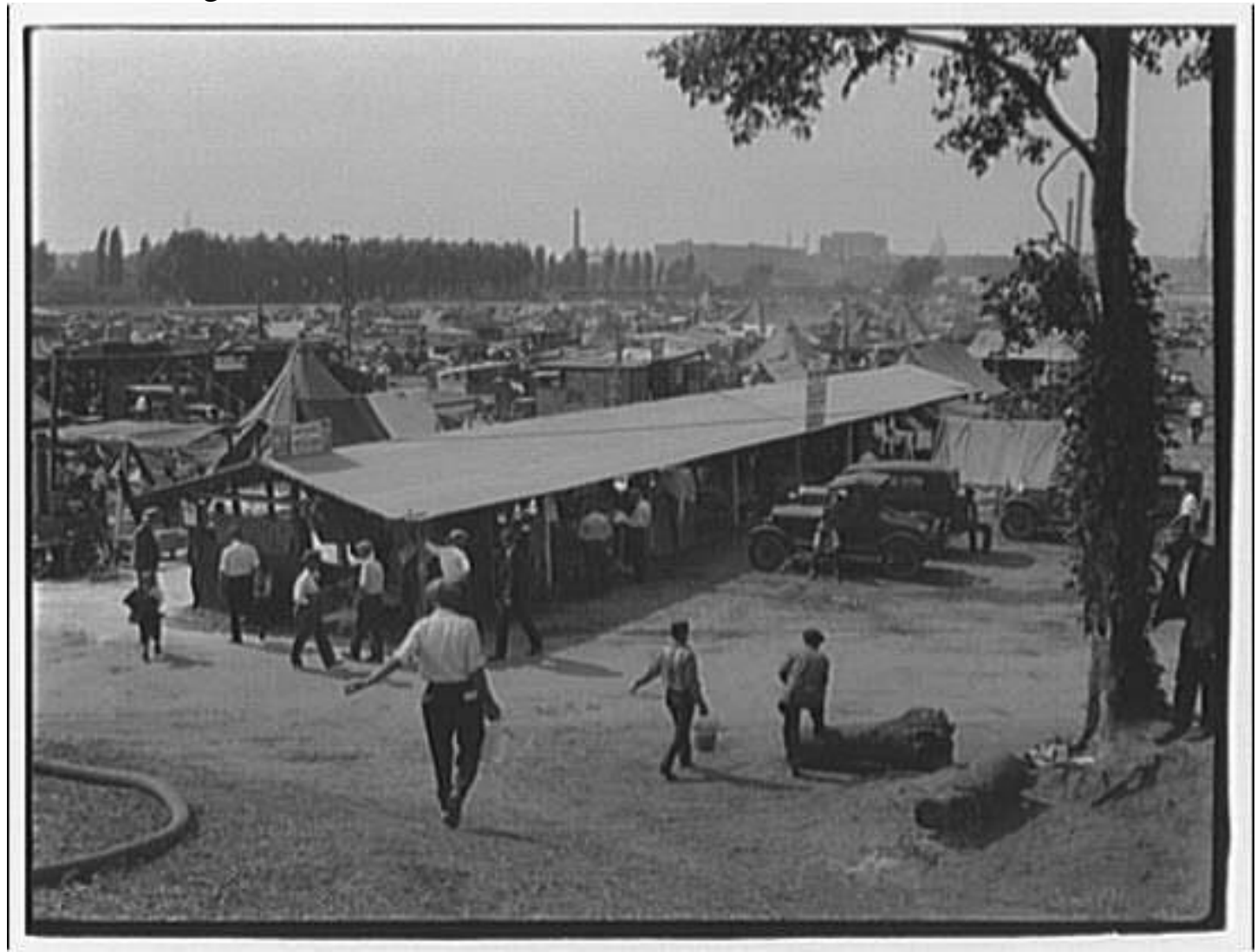

Figure 4.

Horydczak, Theodor. (ca. 1920-1950). Bonus veterans. View of bonus veterans camp. Prints and Photographs Theodor Horydczak Collection. Library of Congress.

Children's literature and (truncated) primary sources provide meaningful opportunities for students to see the complicated nature of history and the incongruous results of various historians' constructions of history. The complications and incongruities present in the secondary narratives that included Bonus Army content provides students a rich opportunity to examine the sources for perspective and bias. In doing so, students scrutinize the primary source material upon which the secondary narrative is based and determine if the claims were corroborated. They utilize various historical thinking skills, or heuristics, as they interpret the primary documents and apply them to the secondary children's narratives (Bickford, 2013b; Nokes, 2011; Wineburg, 2001).

Students can also assess the intentions of the authors that chose to not incorporate Bonus Army content. This activity both facilitates students' inspection of the authors' decisions to omit the content entirely and elicits students' interest to locate more primary source material. A simple Internet search will reveal photographs of tidy, modestly dressed, jubilant veterans standing next to an unassuming, smiling Eleanor Roosevelt. Students can use such visual evidence to corroborate two children's narratives (Fleming, 2005; Freedman, 1993), dispute 
another's characterization (Winner, 2004), and question why the majority of books disregarded her demonstrable concern. The photographs, though, are not released for publication but can easily be located online (Bettmann, 1933; O’Malley, 2011). The above primary sources, and others located within the Library of Congress, can assist students' examinations of the omissions of Bonus Army content within certain authors' narratives and the incongruities within other authors' narratives that included Bonus Army content.

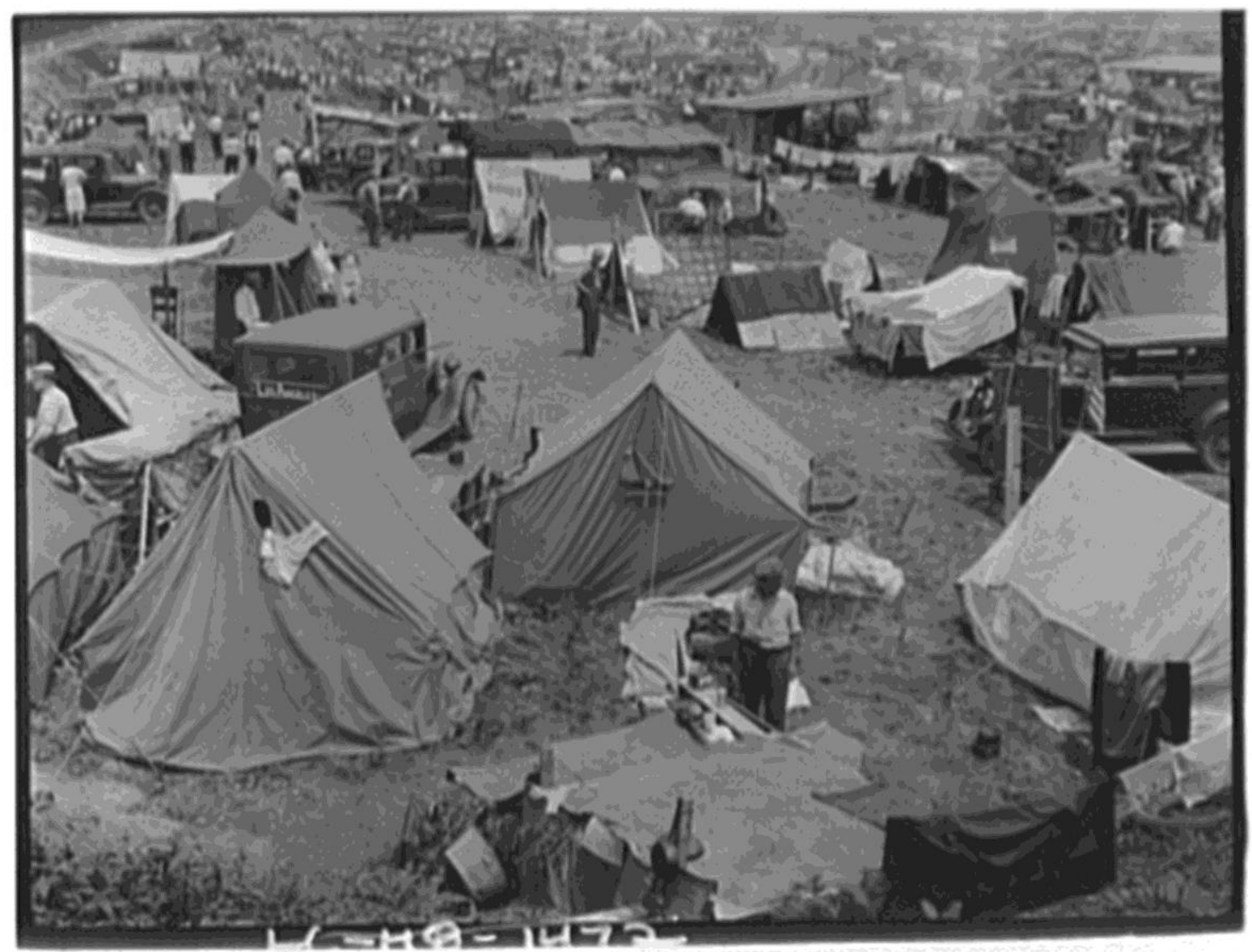

Figure 5. Horydczak, Theodor. (ca. 1920-1950). Bonus veterans. Camp B.E.F. Prints and Photographs. Theodor Horydczak Collection. Library of Congress.

\section{Primary Sources that Address Historical Misrepresentations}

Whereas the previous section addresses a specific historical event, the subsequent historical documents address the more general patterns of historical misrepresentation noted above in the content analysis. We have purposely not duplicated the significant digital and print primary source collections generated by the National Archives, Historical Thinking Matters, and Jackdaw Publications of Primary Source Documents. These (truncated) primary sources are rich in content, varied in form, and can buttress students' understandings of the historical figures' lives and legacies.

This first group illustrates lynching in early 20th century America. Rosa Parks, Eleanor Roosevelt, and Helen Keller all actively opposed lynching. Some of the documents are explicitly 
tied to a single historical figure; all of the documents can be universally applied to each of the historical figures' disdain for and opposition to lynching.
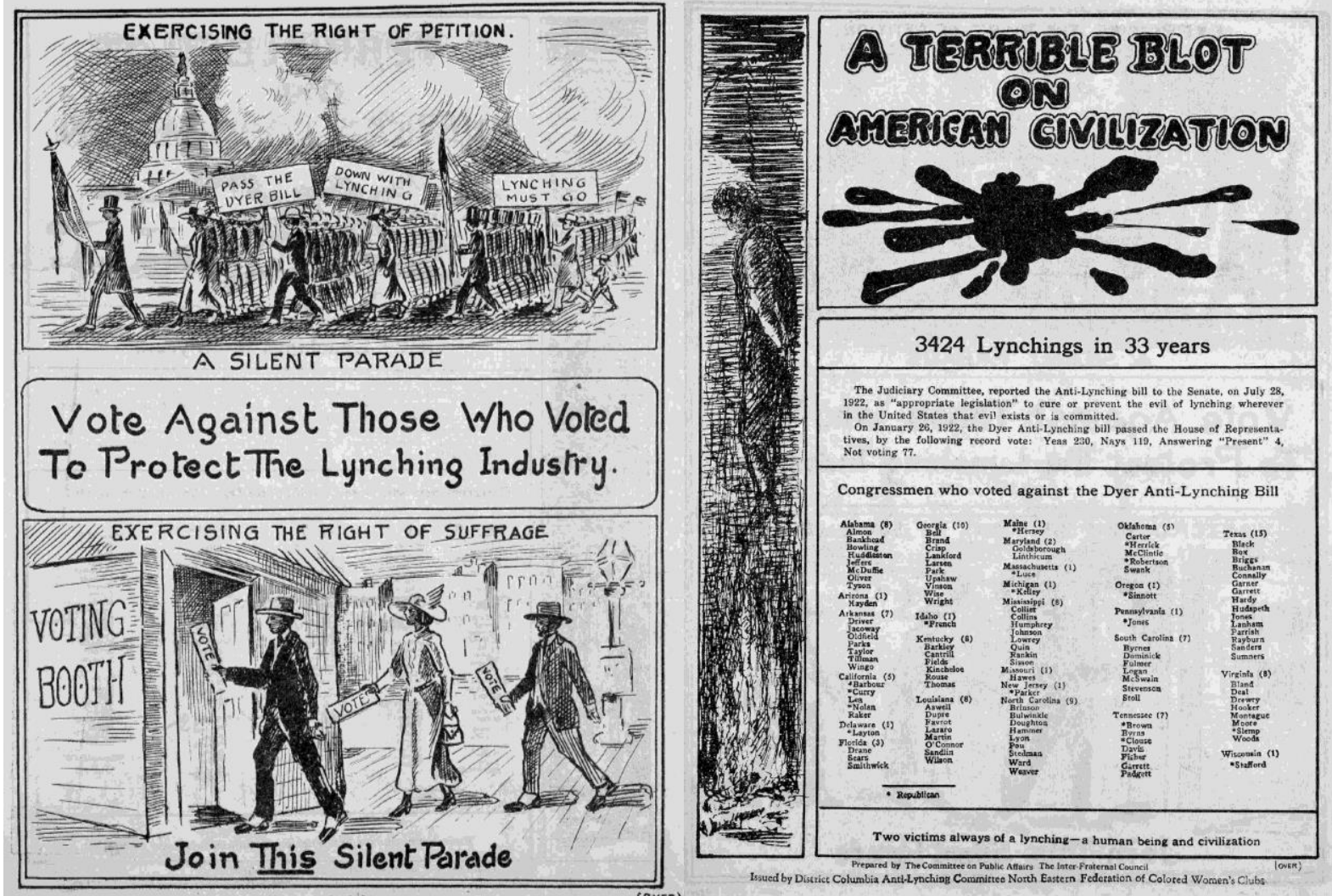

Figure 6. A terrible blot on American civilization. 3424 lynchings in 33 years ... Prepared by the Committee on public affairs The Inter-fraternal council. Issued by District of Columbia anti-lynching committee North eastern federation of Colored women's. (1922) American Memory Collection An American Time Capsule: Three Centuries of Broadsides and Other Printed Ephemera. Library of Congress. 


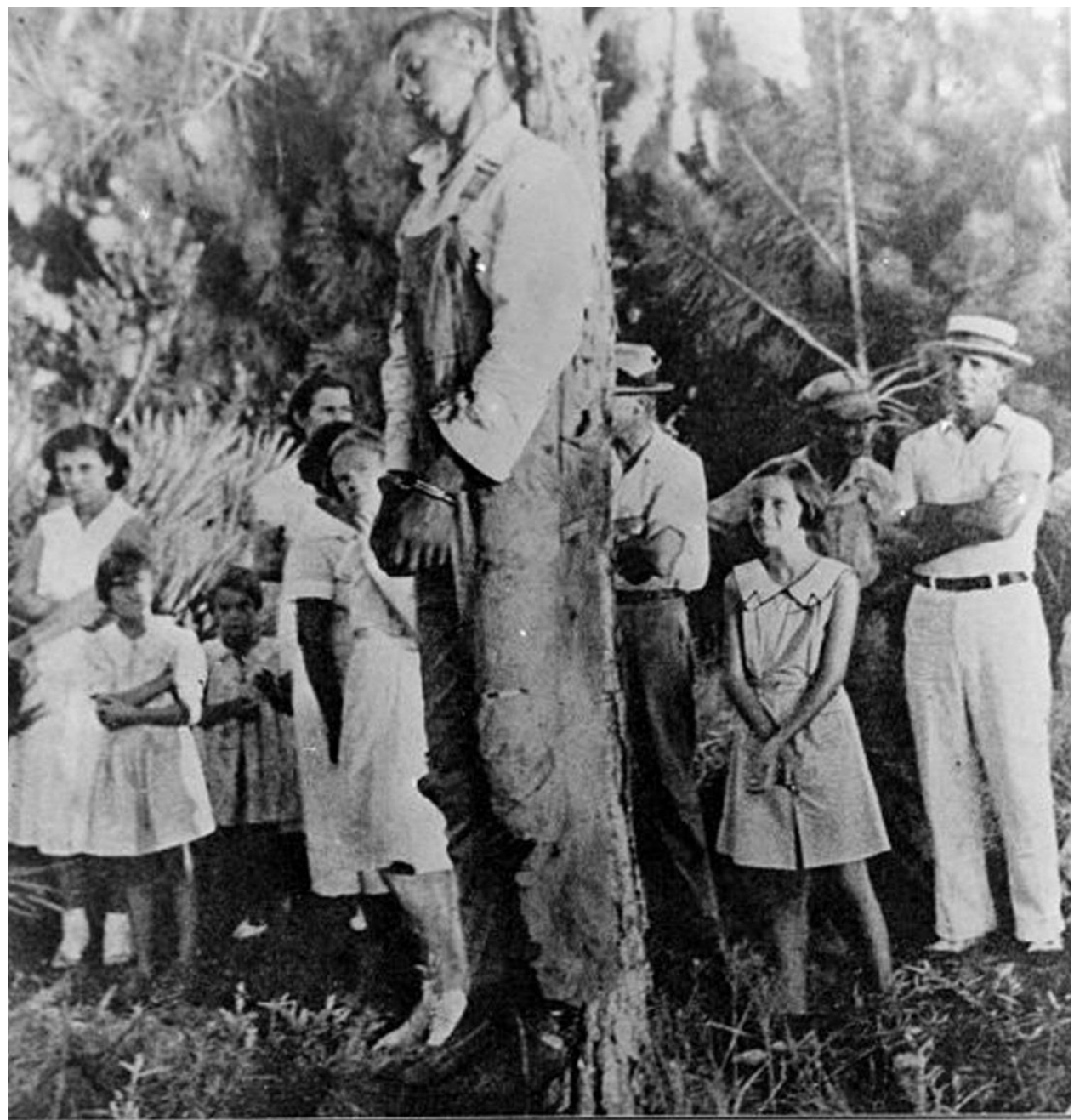

Figure 7. Lynching of R. Stacey - Fla. 1935 - Negro hanging from tree amid crowd of men, women, and children. (1935). Prints and Photographs. Library of Congress.

PERSONAL AND CONFIDENTIAL

The White House

Washington

March 19, 1936

My dear Mr. White:

Before I received your letter today I had been in to the President, talking to him about your letter enclosing that of the Attorney General. I told him that it seemed rather terrible that one could get nothing done and that I did not blame you in the least for feeling there was no interest in this very serious question. I asked him if there were any possibility of getting even one step taken, and he said the difficulty is that it is unconstitutional apparently for the Federal Government to step in the lynching situation. The Government has only been allowed to do anything about kidnapping because of its interstate aspect, and even that has not as yet been appealed so they are not sure that it will be declared constitutional. 
The President feels that lynching is a question of education in the states, rallying good citizens, and creating public opinion so that the localities themselves will wipe it out. However, if it were done by a Northerner, it will have an antagonistic effect. ... I am deeply troubled about the whole situation as it seems to be a terrible thing to stand by and let it continue and feel that one cannot speak out as to his feeling. I think your next step would be to talk to the more prominent members of the Senate.

Very sincerely yours,

Eleanor Roosevelt

Figure 8. White, Walter. (1939). Letter from Eleanor Roosevelt to Walter White, March 19, 1936. NAACP Records, Manuscript Division. Library of Congress.

NEWS FROM NAACP National Association for the Advancement of Colored People 20 West 40th Street New York 18. N. Y. Longacre 3.6890

Roy Wilkins Henry Lee Moon Executive Secretary Relations Director of Public FOR RELEASE: SEPTEMBER 1, 1955

\section{LYNCHING OF SCHOOLBOY LAID TO WHITE SUPREMACY DRIVE IN MISSISSIPPI}

NEW YORK, Sept. 1.--Following the lynching in Mississippi of a 14- year-old Negro boy whose body was found yesterday, the top officer of the NAACP charged that "it would appear from this lynching that the State of Mississippi has decided to maintain white supremacy by murdering children,"

In a statement, issued yesterday, Roy Wilkins added: "The killers of the boy felt free to lynch him because there is in the entire state no restraining influence of decency."

Mr, Wilkins, NAACP executive secretary, simultaneously dispatched a telegram to the Hon. Hugh White, governor of Mississippi, asserting:

"...All decent citizens throughout the nation call upon you to use all the powers of your office to see that the lynchers of 14-year-old Emmett Louis Till are brought to justice. We cannot believe that responsible officials of the State of Mississippi condone the murdering of children on any provocation."

A reply received from Gov. White at NAACP headquarters here today said, in part:

"Parties charged with murder are in jail and I have every reason to believe the courts will do their duty in prosecution. Mississippi does not condone such conduct."

The youthful lynch victim, who was visiting an uncle in Money, Miss., while on vacation from his native city of Chicago, was kidnapped from his uncle's residence on Aug, 27 by two white men and a woman, Roy Bryant of Money, and his half- brother, J.W. Milam of Glendora, Miss., admitted kidnapping the boy but insisted they released him unharmed. The two men, arrested for kidnapping, now are being held on a murder charge.

The woman in the case, Mrs. Bryant, has disappeared. A warrant charging kidnapping has been issued against her. 
The body of the schoolboy was found in the Tallahatchie River near Greenwood, Miss., with a bullet through the head. The boy' s head also bore the marks of a beating with a heavy instrument.

Cause for the lynching is said to be Mrs. Bryant's offense because the 14-year-old lad whistled at her.

In Chicago, where the victim's mother lives, the local NAACP branch telegraphed President Eisenhower and Attorney General Herbert Brownell for a federal investigation of the crime.

At a press conference today, Governor White announced that he has instructed the district attorney to make a complete investigation of the killing.

The last recorded lynching in the U.S. occurred in 1951, in Winter Garden, Fla., according to NAACP records.

Figure 9. NAACP. (1955). Press release concerning the lynching of Emmett Till, September 1, 1955. NAACP Records, Manuscript Division. Library of Congress.

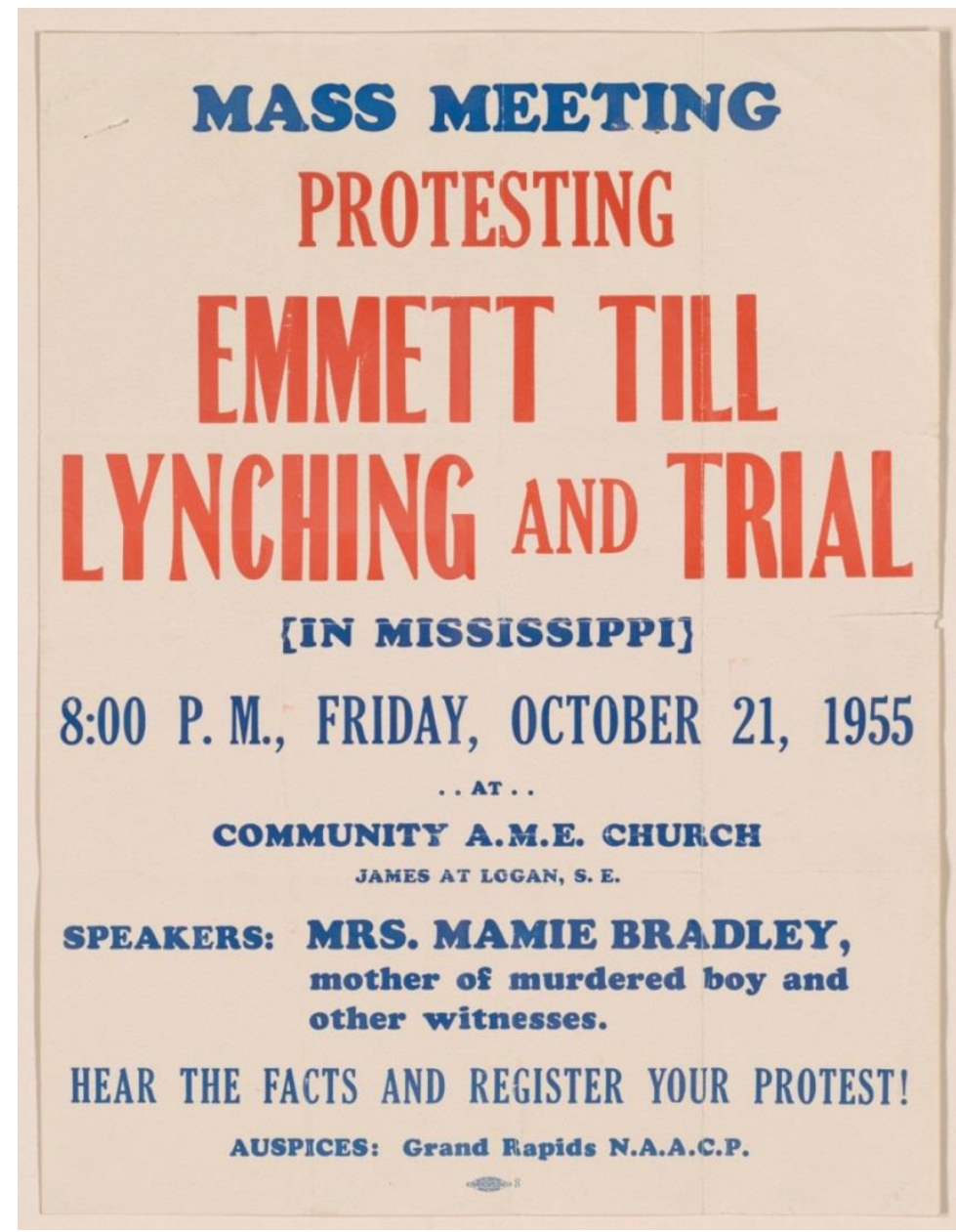

Figure 10. NAACP. (1955). Mass Meeting Protesting Emmett Till Lynching and Trial [in Mississippi] 8:00 P.M., Friday, October 21, 1955 at Community A.M.E. Church., [1955]. NAACP Records, Manuscript Division. Library of Congress. 
Figure Six terms lynching to be a "terrible blot on American civilization" as it demonstrates its ubiquity. Figure Seven demonstrates the unconcealed nature of lynching; the familial scene indicates a banality that seems unimaginable today. Figure Eight denotes both Eleanor Roosevelt's opposition to lynching and impotence to compel President Roosevelt to intervene. Figures Nine and 10 indicate the NAACP's outrage at and response to the Till lynching. Eleanor Roosevelt's resistance to lynching is explicit in Figure Eight yet all three historical ladies actively opposed lynching. Children's authors, however, did not capture their resistance. Further, the timing of Till's murder (along with his young age, national media coverage, and his murderers' avoidance of punishment) enraged Southern activists like Parks, a fact that the examined literature similarly disregarded. These primary sources both complicate and historically balance the simplistic narratives, yet their content is too graphic for young children. It is prudent to withhold lynching from the curriculum until the children are at an age where they can better understand its causes and implications. To reduce White America's mistreatment of African Americans, however, to mere images of separate drinking fountains appears disingenuous. The subsequent primary sources illustrate the harsh disparity that emerged under claims of separate but equal.

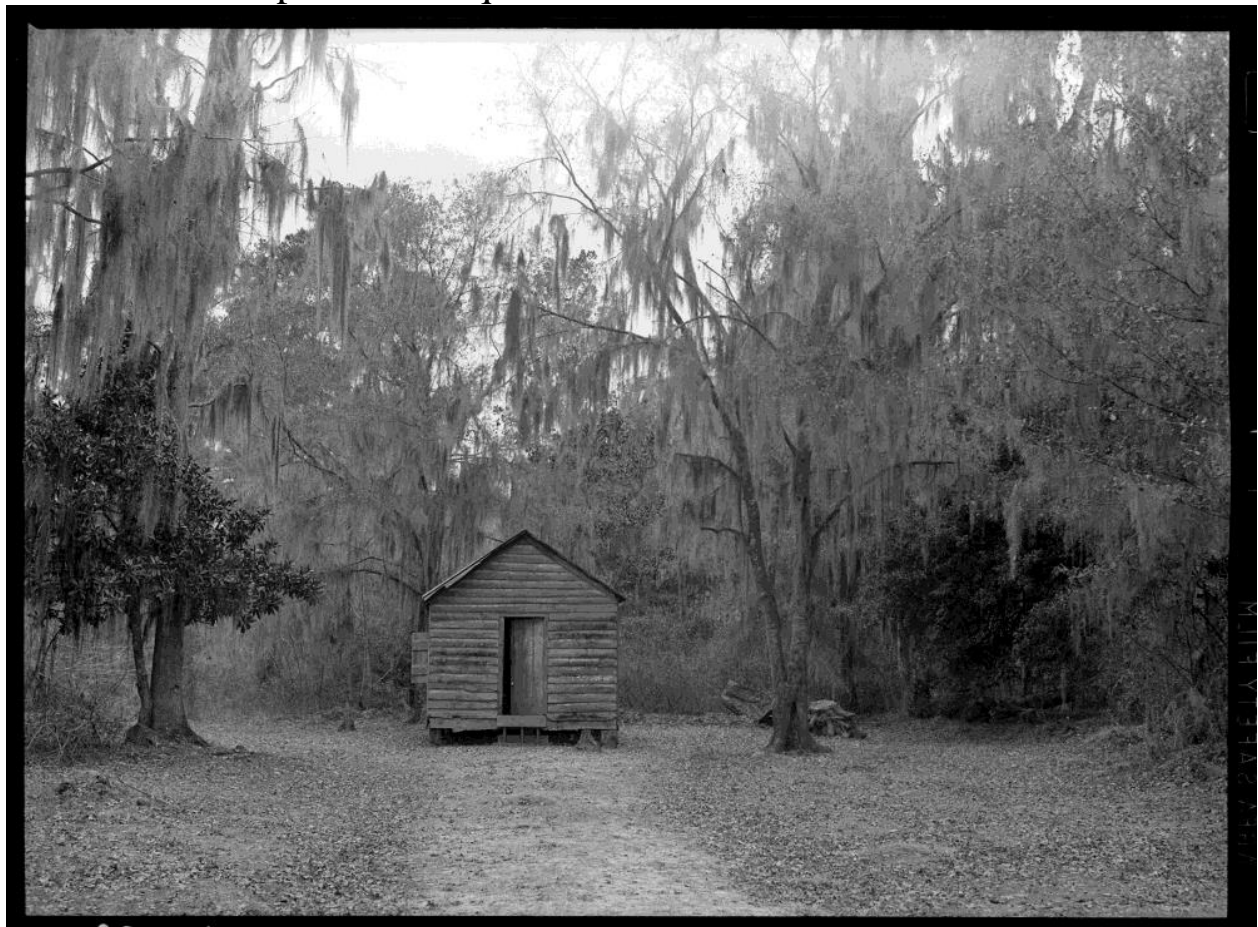

Figure 11. Wolcott, Marian Post. (1938 Dec.). Negro schoolhouses near Summerville, South Carolina . Prints and Photographs Division. Library of Congress. 


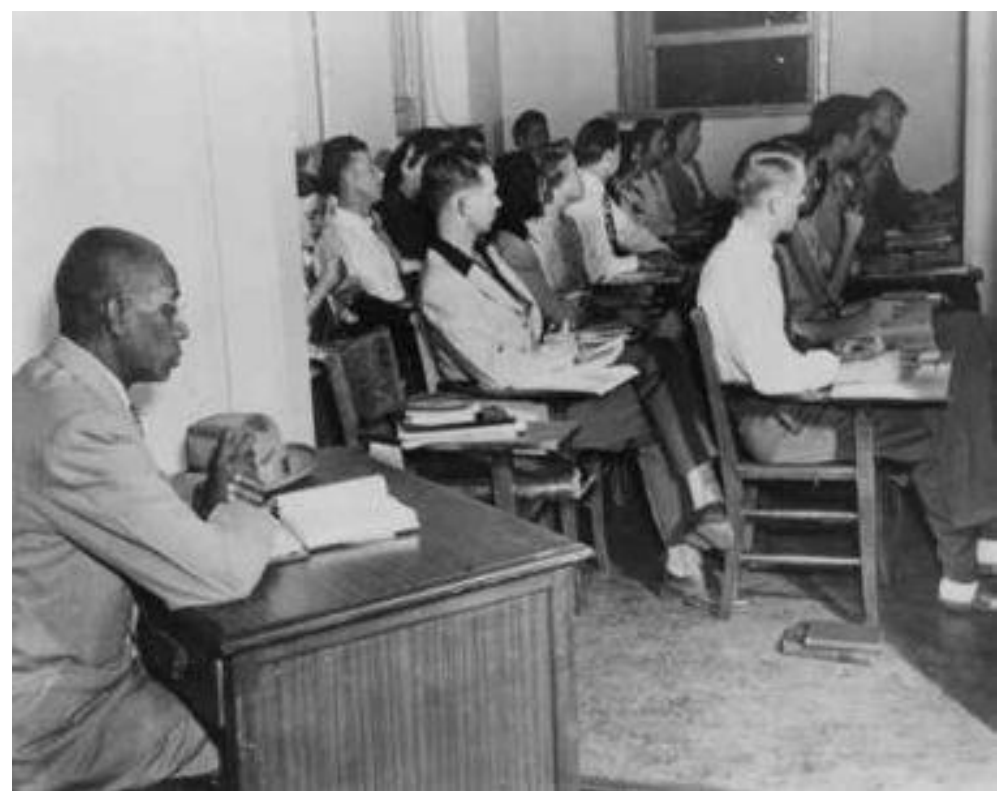

Figure 12. White students in class at the University of Oklahoma, and G.W. McLaurin, an African American, seated in anteroom (1948) Prints and Photographs. Library of Congress.

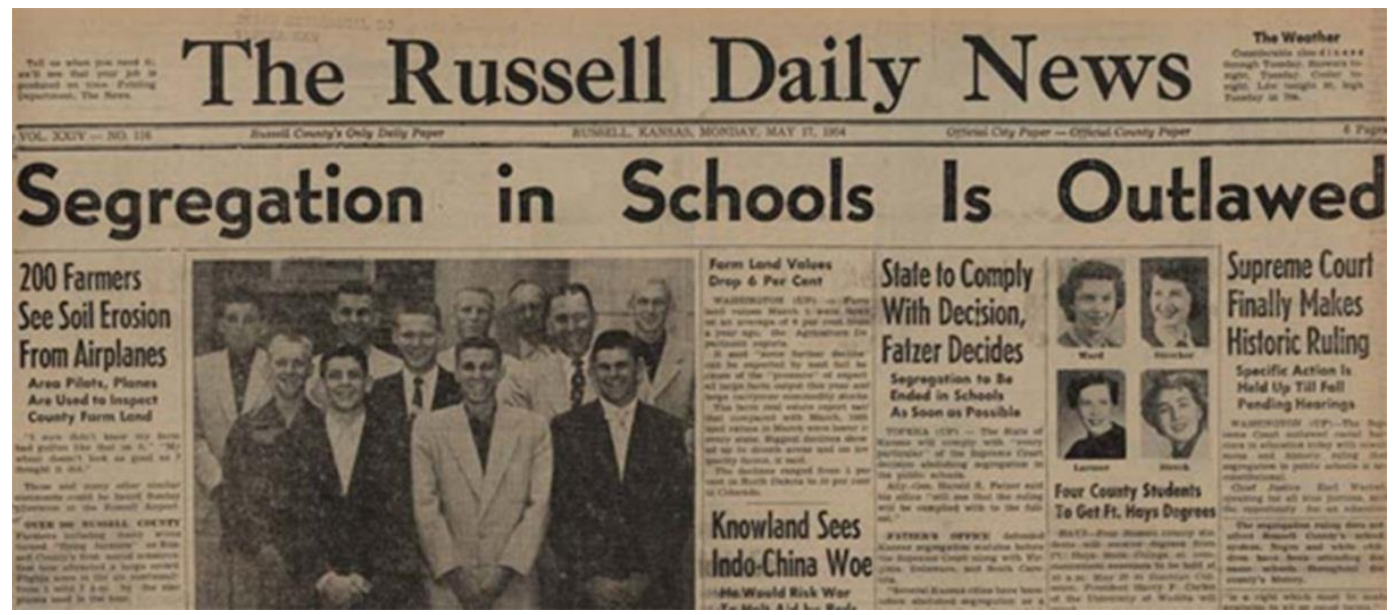

Figure 13. The Russell Daily News (Russell, Kansas), Monday, May 17, 1954. Historic Events Newspaper Collection, Serial and Government Publications Division, Library of Congress. 


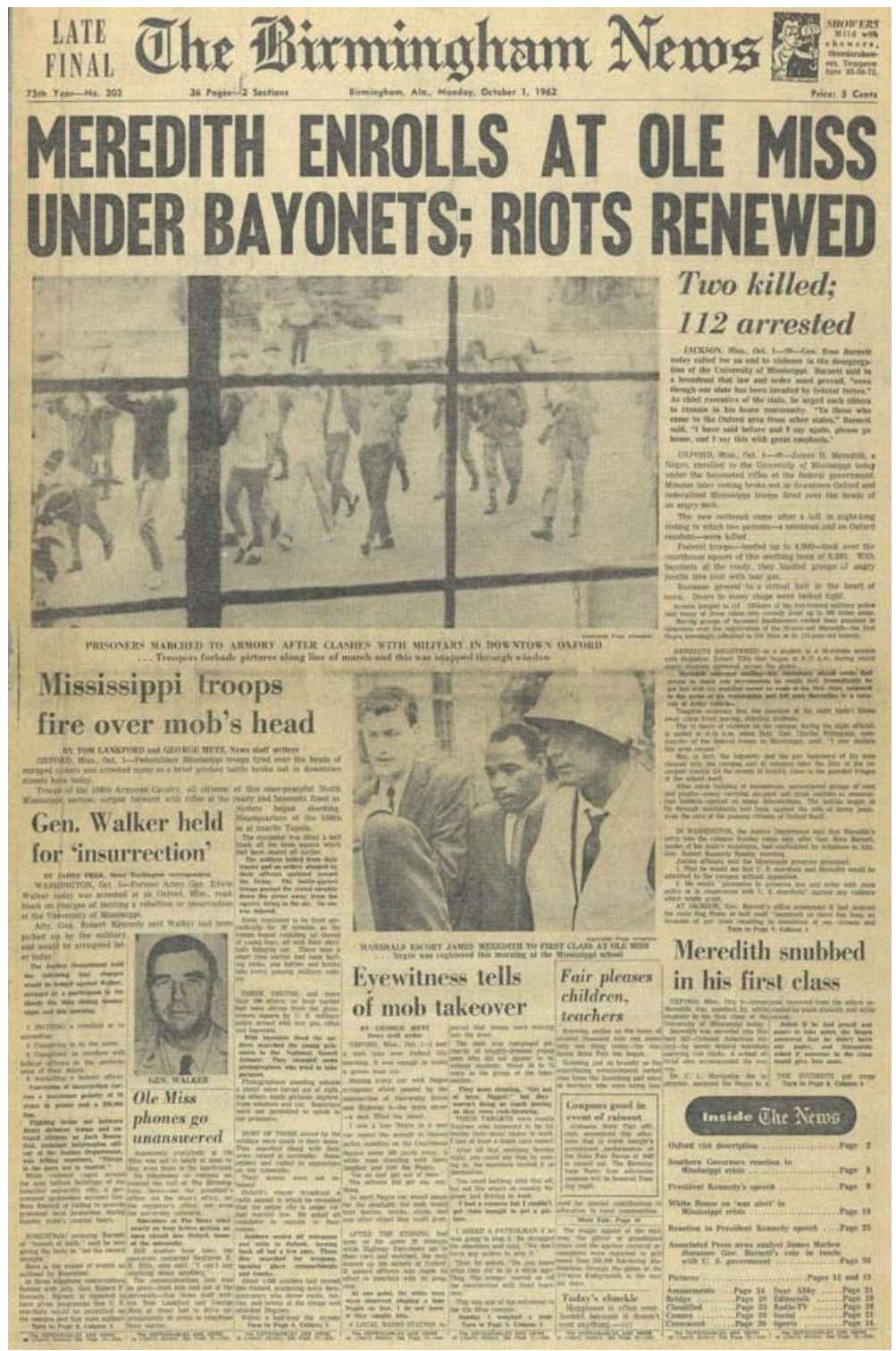

Figure 14. The Birmingham News (Birmingham, Alabama), Monday, October 1, 1962. Newspaper. Historic Events Newspaper Collection, Serial and Government Publications Division. Library of Congress.

The cabin-like appearance within Figure 11 denotes an isolation and deficiency of support that is not captured in the concept of separate but equal. Figure 12 explicitly represents social separation with the African American man in the foreground and implicitly indicates White Americans' motivation to marginalize. The accomplishment of desegregation and resistance to such desegregation are represented in Figures 13 and 14. Figures 11, 12, 13, and 14 indicate the harsh realities of segregation and resistance to desegregation (sans violence) that elicited all three historical figures advocacy and sympathy.

The children's literature largely noted Roosevelt's resistance to segregation by mentioning her support for Marian Anderson's concert and African American soldiers. The 
children's literature about Parks, similarly, highlighted her parallel stance yet largely ignored Keller's advocacy for integration. Figures 15 and 16 exhibit Roosevelt's promotion of integration as Figure 17 suggests this position, while unpopular in certain segments of society, was not entirely anomalous.

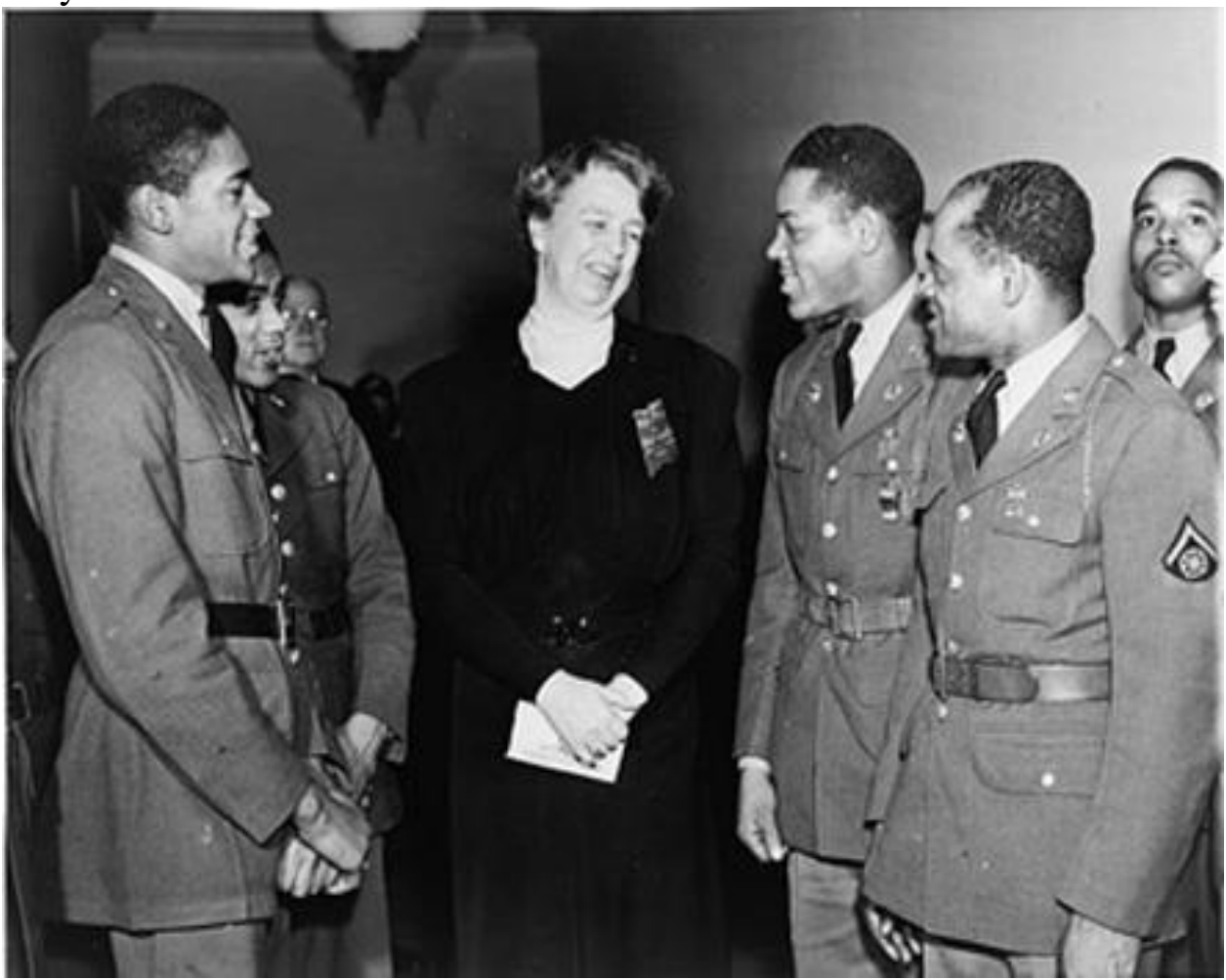

Figure 15. First Lady greets colored troops. (1942). Prints and Photographs. Library of Congress.

\begin{tabular}{|c|}
\hline $\begin{array}{l}\text { April } 12^{\text {th }} \\
1939\end{array}$ \\
\hline $\begin{array}{l}\text { My dear M } \\
\text { Tha } \\
\text { of the most } \\
\text { be there. B } \\
\text { We } \\
\text { press confe } \\
\text { Spingarn } \mathrm{T} \\
\text { Webb and } \\
\text { make the p } \\
\text { know that } \\
\text { Anderson. }\end{array}$ \\
\hline
\end{tabular}


Ever sincerely,

[Walter White NAACP] Secretary.

Figure 16. White, Walter. (1939). NAACP Secretary Walter White to Eleanor Roosevelt concerning Marian Anderson's Easter Sunday concert and Spingarn Medal, April 12, 1939. NAACP Records, Manuscript Division. Library of Congress.

FEDERAL REGISTER

JULY 28, 1948

TITLE 3-The PRESIDENT

EXECUTIVE ORDER 9980

Regulations Governing Fair Employment Practices Within the Federal Establishment WHEREAS the principles on which our Government is based require a policy of fair employment throughout the Federal establishment, without discrimination because of race, color, religion, or national origin; and WHEREAS it is desirable and in the public interest that all steps be taken necessary to insure that this long-established policy shall be more effectively carried out...

HARRY S. TRUMAN

THE WHITE HOUSE, July 26, 1948

Figure 17. Truman. (1948). J.L. Executive Order 9980, July 26, 1948. NAACP Records, Manuscript Division. Library of Congress.

Integration, when fully historicized, was not universally accepted during the first half of the 20th century but has since gained collective societal support. The children's literature, as noted, largely acknowledged Eleanor Roosevelt's advocacy for integration. Labor activism has remained a relatively polarized position determined largely by the activist's socioeconomic position. Roosevelt's high society birth position made her labor activism appear uncommon. The children's books, as noted, largely disregarded her advocacy for working class labor issues. When properly sourced, Figures 18 and 19 reveal her labor activism and tranquility interacting with workers. 
Social Studies Research and Practice www.socstrp.org

Figure 18. Horne, Joseph A. (1944) Washington, D.C. Eleanor Roosevelt arriving at the opening of the Washington labor canteen, sponsored by the United Federal Workers of American, Congress of Industrial Organizations (CIO) Prints and Photographs. Library of Congress. 


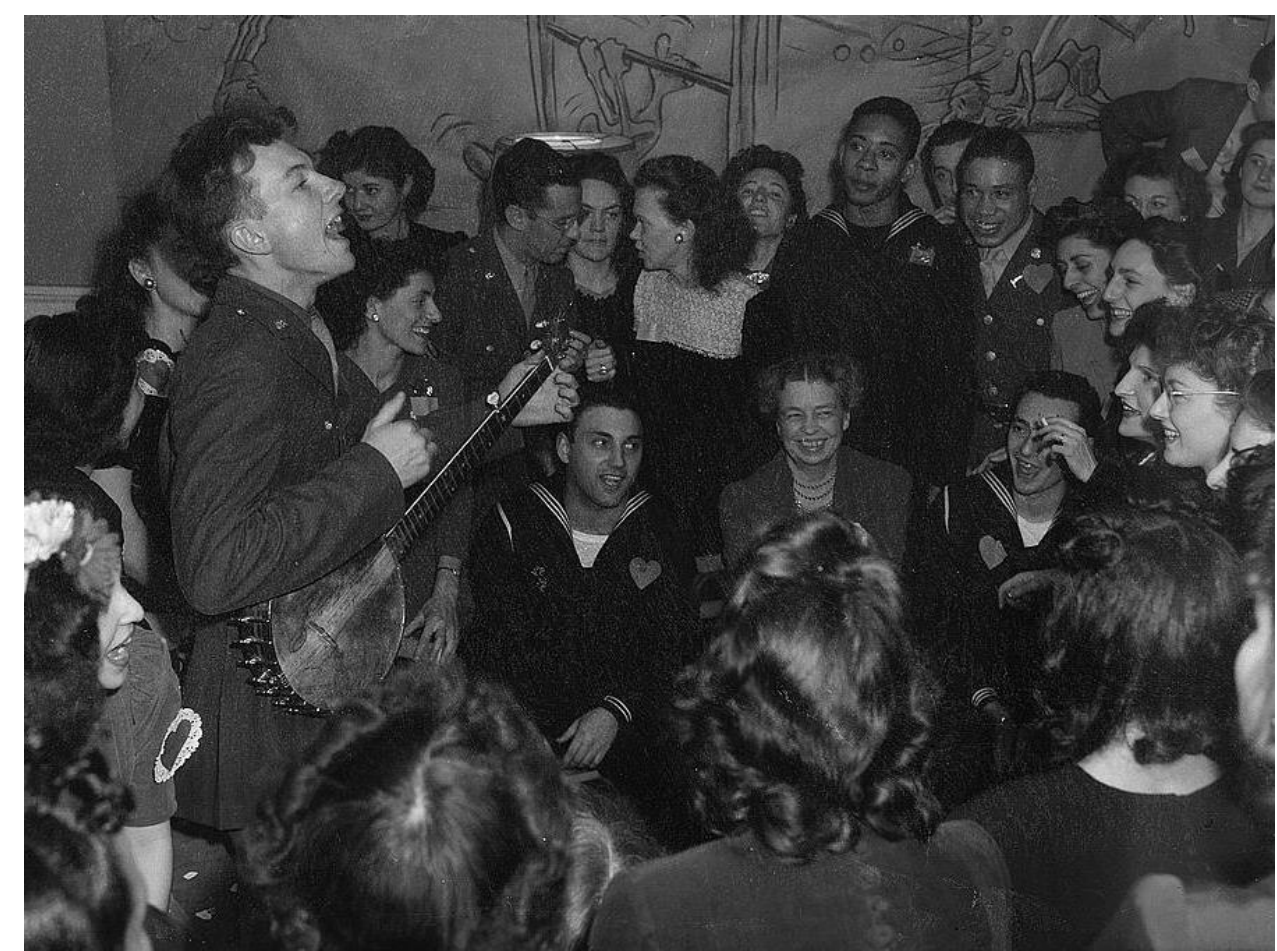

Figure 19. Horne, Joseph A. (1944) Washington, D.C. Pete Seeger, noted folk singer entertaining at the opening of the Washington labor canteen, sponsored by the United Federal Labor Canteen, sponsored by the Federal Workers of American, Congress of Industrial Organizations (CIO). Prints and Photographs. Library of Congress.

Eleanor Roosevelt's labor advocacy, as mentioned, contrasted sharply with the nature of a child born to high society in Victorian America. Most young readers will not likely grasp the concept of the socially elite within Victorian America or the disparate lives that so many others lived. Figure 20 illustrates the former and Figure 21 the latter. Keller, similarly, advocated for labor issues, which belied her financially secure (if not socially elite) birth position. 


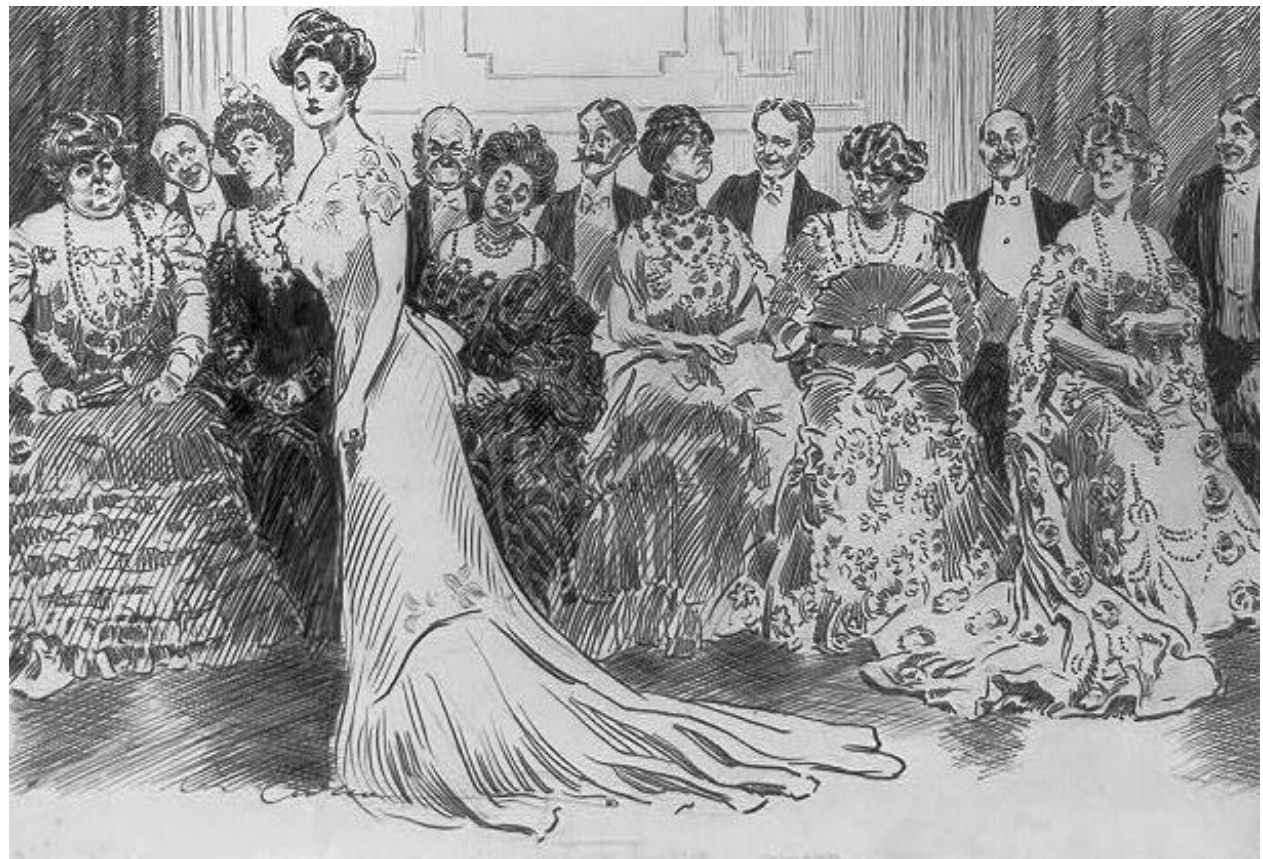

Figure 20. Gibson, Charles Dana. (1904). The jury disagrees. Prints and Photographs. Library of Congress.

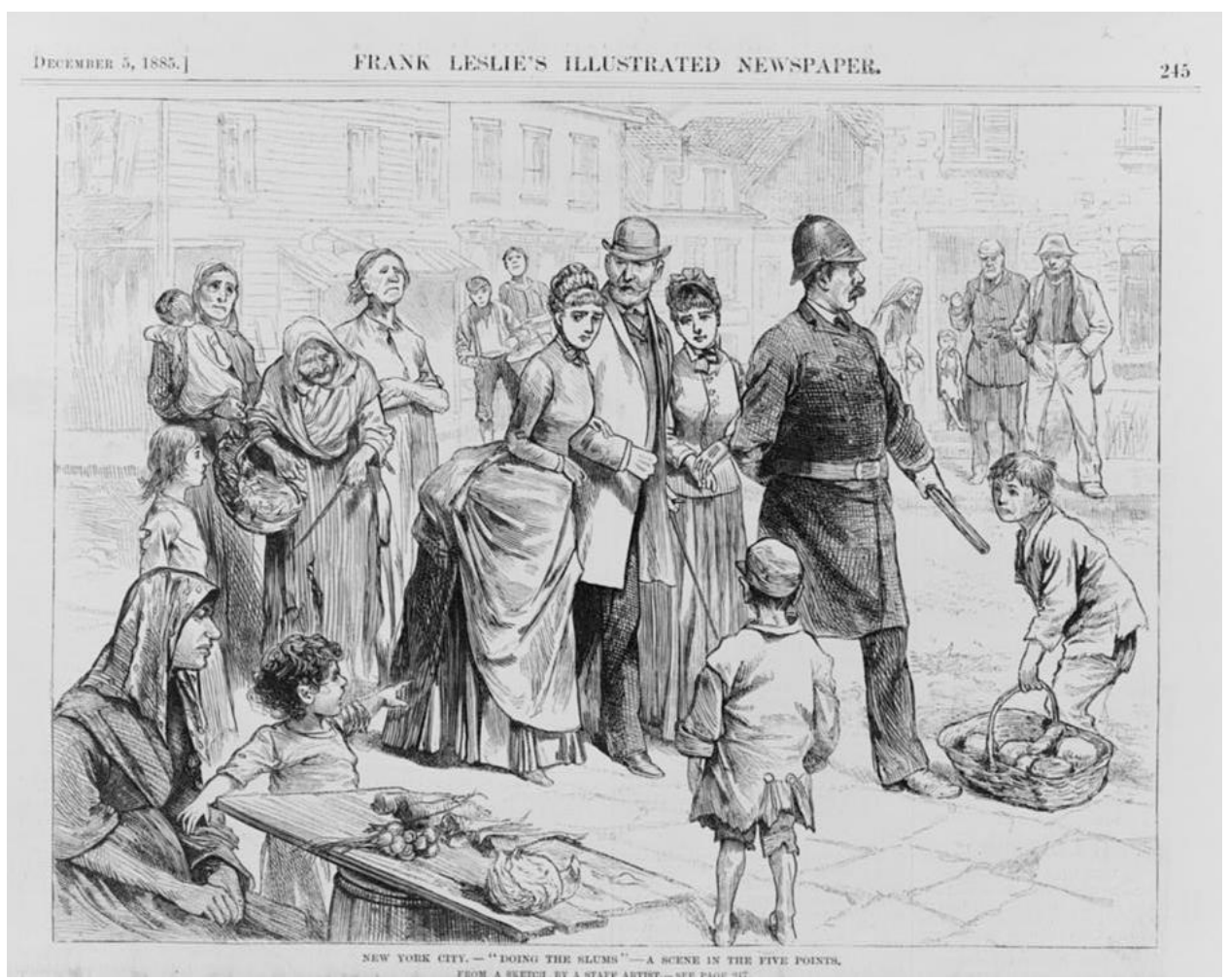

Figure 21. Illus. in: Frank Leslie's illustrated newspaper, v. 61, (1885 Dec. 5), p. 245. New York City - "Doing the slums" - A scene in the Five Points / from a sketch by a staff artist. Prints and Photographs. Library of Congress. 
The omissions within children's literature about Keller's life's missions can similarly be balanced with primary source material. Figures 22, 23, and 24 highlight the significant support, financial and otherwise, Keller received. Not intended to detract from Keller's accomplishments, this correspondence counters the heroification and exceptionalism young readers will infer from Keller-based children's literature. Figure 25, a collection of newspaper headlines on a page from Keller's scrapbook, illustrates that her interests included far more than advocacy for the disabled.

A.H. Keller, Editor and Proprietor of the North Alabamian. $\$ 1.50$ Per Year. Established 1881

Dr. Alex G Bell Tuscumbia, Alabama, Aug $13^{\text {th }} 1894$ My dear Sir

I have waited to hear from Miss Sullivan before answering your kind letter which was received ten days or two weeks ago.

From the letter just received, Miss Annie seems to prefer the Wright-Humason School at New York, and as much depends upon her wishes, I have written to her and requested that she confer with you before deciding what to do, and suppose that e'er this you have heard from her and Helen.

I wrote Miss Annie that I did not think it would be prudent to come home this Summer. If she and Helen expected to enter school $1^{\text {st }}$ October.

We have had a delightful summer until the last three or four days, which have been very hot. Ninety three degrees is the highest temperature we have had and that only for a few days. During July my thermometer never marked higher than $85^{\circ}$....

Helen was much concerned before she left about a plan, which she said you were considering, to convey the cold air of our Northern latitudes to the South in Summer and the warm air of the South to the North in Winter. The summer part of the program would not have worked well this year. You would have had to reverse the currents.

I hope your family have all kept well. We have had no sickness, and have made no changes in our abode.

My wife joins me in best wishes for you all.

Very sincerely \& truly yrs

A H Keller

Figure 22. $\quad$ Letter from Arthur H. Keller to Alexander Graham Bell, August 13, 1894. Alexander Graham Bell family papers, 1834-1974 Collection. Manuscript Division. Library of Congress. http://www.loc.gov/item/magbellbib004016 
Office of United States Marshal,

Northern District, Alabama

Prof Graham Bell

Tuscumbia Huntsville, Ala., Nov. $29^{\text {th }} 1889$

My dear Sir

Washington DC

Remembering how very kind you were to my little deaf, dumb and blind girl whilst we were in Washington last winter, and how much interest you expressed in her behalf, it affords me great pleasure to report that her progress in learning is phenomenal and the effort of it almost staggering over credulity who has not seen it.

In March last I secured the services of Miss Annie Sullivan a graduate of the Perkins Institution at Boston, who was educated whilst blind, and had her sight restored last year by an operation. In a month the little girl (Helen) learned to spell about four hundred words and in less than three month can write a letter, unaided by any one.

In six weeks she mastered the "Braile" (French) System which is cipher for the blind enabling them to read what they have written.

She has also mastered addition, multiplication and subtraction and is progressing finely with Geography.

Miss Sullivan has sent Prof Anagnos a short sketch of her life and her progress in her studies which will shortly appear in the Annual Report of the Perkins Institution.

I send you a picture of Helen and her Teacher and also a specimen of her writing believing you will be glad to hear again from the dear little treasure.

With high regard I am very truly yours

A H Keller

Figure 23. $\quad$ Letter from Arthur H. Keller to AlexanTder Graham Bell, November 29, 1887. Alexander Graham Bell family papers, 1834-1974 Collection. Manuscript Division. Library of Congress. http://www.loc.gov/item/magbellbib002598

Geo O. Goodhue Danville PQ, Canada Copy Danville, P.Q., 13 April, 1894.
My Dear Miss Sullivan:
.. When I first saw Mr. Spaulding in his office, now just a week ago, I found
him quite busy, but pleasant and kindly. He explained what he had already done for
Helen's father, as well as for herself, but did not seem to have had any special
thought as to provision for Helen's future. On Monday I had my first good long talk
with him, and explained the plan to which I had given a good deal of thought. It was
briefly this: first, to ascertain the amount required each year for five years to come
for Helen and you as her teacher and friend, then allow a good margin, and then let
the friends who we think would consider it a privilege to do so have the chance to
help us make up this amount, with the understanding that it is to be continued for
five years, or as much longer as may be necessary. Should the amount thus raised be
more than sufficient for the purposes designed, the proposition is to make any
surplus the nucleus of a permanent fund.
He thinks, with me, that Helen should be kept from the public as much as it
is possible, at least for a time. Perhaps I feel too strongly about this, as I have seen


so very little of her, and, therefore, do not really know, but it does seem to me to be of very high importance for Helen's best good. Her development has in every way been so miraculous almost, that were she anybody but her own sweet self, she would surely been injured by the public attention showered upon her. Few, it seems to me, could stand without injury, even in maturer years, one-half of the just need of praise and appreciation that are due to the wonderful gifts and charming disposition of our dear little sister.

I hope your eyes are much better. When they will permit, please let me know what kind of a school you would prefer for Helen, and where you think would be the best place for to be, whether Boston or elsewhere. The reason why I am anxious this letter should reach you before Mrs. Hopkins' departure is, of course, that you should impress upon her your ideas as to what is best for Helen, for I feel there is no one more competent to judge, as you know her so much more intimately than even her own parents, who I trust may be pleased with what some of Helen's brothers are desirous of doing to show their love to their dear little sister.

Please give her my love and tell her I will write her before long about my pleasant visit to the kindergarten to see little Tommy and pretty Willie Robin, and the rest.

Very Sincerely Your Friend, Geo. O. Goodhue.

Figure 24. Letter from George O. Goodhue to Annie M. Sullivan, from April 13, 1894 to April 14, 1894. Alexander Graham Bell family papers, 1834-1974 Collection. Manuscript Division. Library of Congress. http://www.loc.gov/item/magbellbib004006 


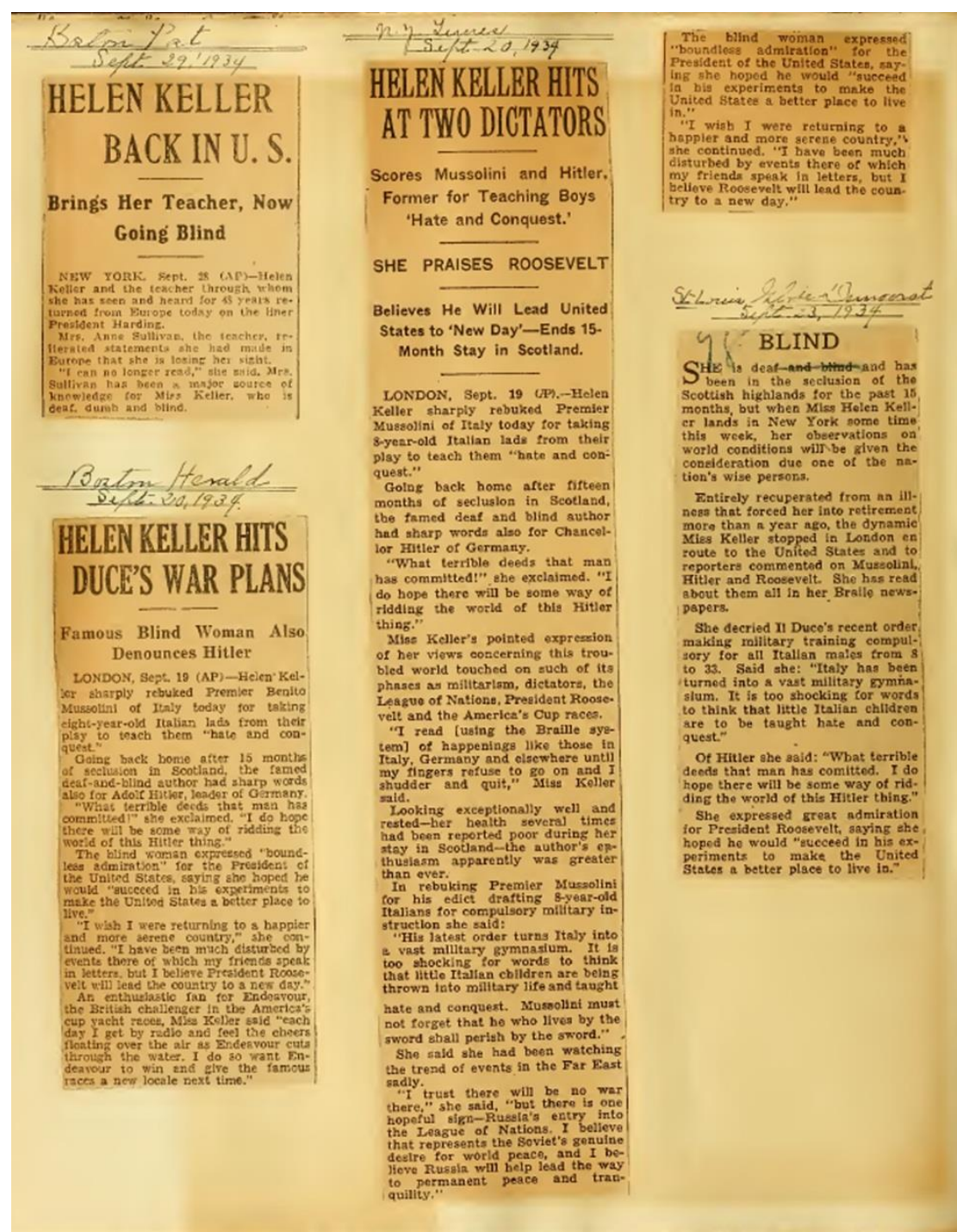

Figure 25. Helen Keller Newspaper Notices (1934) Vol. 19. Digitizing sponsor: Perkins School for the Blind. Samual P. Hayes Research Library, Perkins School for the Blind. Internet Archive. http://archive.org/details/helenkellernewsp19unkn

The primary sources elicit many cognitive responses from the reader. They compel the reader to attend to nuanced details, employ heuristics during interpretation for meaning, apply interpretations to prior knowledge, corroborate accounts, and-potentially - reconstruct historical understandings. In doing so, students discern context-specific language, distinguish authorial bias and perspective, and juxtapose competing first- and second-hand accounts of the same event. Indicative of historical thinking and fulfilling multiple Common Core Reading Informational Texts standards (CCSSI, 2010), such cannot be accomplished without the joint readings of both age-appropriate children's literature and modified supplementary primary source material. 


\section{Discussion}

The purpose of this research was not to ascertain why historical misrepresentations abound in children's literature. It does; this much is clear. The intent was not to compel authors to revise their narratives. They write to sell books to teachers and parents, not for scholars exploring the interconnections between history and education. We do not encourage teachers to abandon the history-based literature they have previously employed. Even those narratives sated with historical misrepresentations can prove invaluable, if used correctly.

This research instead had two goals. First, we intended to explore and report patterns of historical representation within children's literature. The prose and syntax in elementary literature intended may be age-appropriate but the historical content is incomplete. Rosa Parks's story was, largely, compartmentalized to a year of her adult life; Helen Keller was infantilized and her adult missions were sanitized of politics; Eleanor Roosevelt's story was more representatively narrated. Healthy skepticism and cognizance of potential lacunae are paramount for historians and should be for elementary history students and teachers as well. Second, we intended to model for teachers how to overcome the lacunae and historical misrepresentations within children's history-based literature. Authors' biases and inability to incorporate all evidence and perspective are within every historical work, be it primary or secondary. Historybased children's literature provides elementary teachers with secondary historical sources written at developmentally appropriate reading levels. Primary historical sources, like the ones provided above, both complement the secondary accounts and are catalysts to complicate students' historical thinking. We first modeled specificity as we explicitly supplemented Eleanor Roosevelt's Bonus Army involvement with historical sources; we then addressed larger patterns of historical misrepresentations within the other children's literature. Teachers are quite able to follow this approach, which fits within the framework of state and national initiatives.

\section{References}

Baildon, M. \& Baildon, R. (2012). Evaluating online sources: Helping students determine trustworthiness, readability, and usefulness. Social Studies and the Young Learner, 24(4), 11-14.

Beasley, M. (2010). Eleanor Roosevelt: Transformative First Lady. Lawrence, KS: University Press of Kansas.

Bickford, J. (2013a). Examining historical (mis)representations of Christopher Columbus within children's literature. Social Studies Research and Practice, 8(2), 1-24.

Bickford, J. (2013b). Initiating historical thinking in elementary schools. Social Studies Research \& Practice, 8(3), 60-77.

Black, A. (1996). Casting her own shadow: Eleanor Roosevelt and the shaping of postwar liberalism. New York, NY: Columbia University Press.

Bodnar, J. (1985). The transplanted: A history of immigrants in urban America. Bloomington, IN: Indiana University Press.

Brinkley, D. (1999). Rosa Parks: A life. New York, NY: Penguin Books.

Brommel, B. (1978). Eugene V. Debs: Spokesman for labor and socialism. Chicago, IL: Charles H. Kerr Publishing Company.

Bynum, C. (2010). A. Philip Randolph and the struggle for civil rights. Urbana, IL: University of 
Illinois Press.

Center on Education Policy (2008). Instructional time in elementary schools: A closer look at changes for specific subjects. Washington, D.C.: CEP.

Chick, K. (2006). Gender balance in k-12 American history textbooks. Social Studies Research and Practice, 1(3), 284-290.

Chick, K. \& Corle, S. (2012). A gender analysis of NCSS Notable Trade Books for the intermediate grades. Social Studies Research and Practice, 7(2), 1-14.

Chick, K., Slekar, T., \& Charles, E. (2010). A gender analysis of NCSS Notable picture book winners: 2006-2008. Social Studies Research and Practice, 5(3), 21-31.

Collins, F. \& Graham, J. (2001). Historical fiction for children: Capturing the past. London, UK: David Fulton Publishers.

Common Core State Standards Initiative (2010). Common Core state standards for English/language arts and literacy in history/social studies, science, and technical subjects. Washington, DC: Department of Education.

Cook, B. (1984). "Turn toward peace": Eleanor Roosevelt and foreign affairs. In J. Hoff-Wilson \& M. Lightman's (eds.), Without precedent: The life and career of Eleanor Roosevelt (108-121). Bloomington, IN: Indiana University Press.

Cook, B. (1992). Eleanor Roosevelt: Volume one, 1884-1933. New York, NY: Viking.

Cook, B. (1999). Eleanor Roosevelt: Volume two, 1933-1938. New York, NY: Viking.

Council of Chief State School Officers (2012). Vision for the college, career, and civic life (C3) framework for inquiry in social studies state standards. Washington, DC: Department of Education.

Drake, F. \& Brown, S. (2003). A systematic approach to improve students' historical thinking. The History Teacher, 36(4), 465-489.

Dyson, M. (2000). I may not get there with you: The true Martin Luther King, Jr. New York, NY: Simon \& Schuster.

Einhorn, L. (1998). Helen Keller, public speaker: Sightless but seen, deaf but heard. Westport, CT: Greenwood Press.

Fitzgerald, J. (2009). Textbooks and primary source analysis. Social Studies Research and Practice, 4(3), 37-43.

Foner, P. (ed.) (1967). Helen Keller: Her socialist years. New York, NY: International Universities.

Garrow, D. (Ed.) (1989). The walking city: The Montgomery bus boycott, 1955-1956. Brooklyn, NY: Carson Publishing, Inc.

Goodwin, D. (1995). No ordinary time: Franklin and Eleanor Roosevelt: The home front in World War II. New York, NY: Simon \& Schuster.

Graham, J. (2001). The historical picture book - is it a "good thing"? In F. Collins \& Graham (eds.), Historical fiction for children: Capturing the past (54-72). London, UK: David Fulton Publishers.

Greene, M. (2004). Mother Theresa: A biography. New York, NY: Greenwood Press.

Hareven, T. (1968). Eleanor Roosevelt: An American conscience. Chicago, IL: Quadrangle Books.

Hareven, T. (1984). Eleanor Roosevelt and reform. In J. Hoff-Wilson \& M. Lightman's (eds.), 
Without precedent: The life and career of Eleanor Roosevelt (201-213). Bloomington, IN: Indiana University Press.

Herrmann, D. (1998). Helen Keller: A life. New York, NY: Alfred A. Knopf.

Hunter, T. (1997). To 'joy my freedom: Southern black women's lives and labors after the Civil War. Cambridge, MA: Harvard University Press.

Jones, W. (2013). The March on Washington: Jobs, freedom, and the forgotten history of civil rights. New York, NY: W. W. Norton \& Company.

Keller, H. (1913). Out of the dark. Garden City, NY: Doubleday, Page, \& Company.

Keller, H. (1927). My religion. New York, NY: Swedenborg Foundation, Inc.

Keller, H. (1929). Midstream. Garden City, NY: Doubleday, Doran, \& Company.

Kline, W. (2008). Developing and submitting credible qualitative manuscripts. Counselor Education \& Supervision, 47, 210-217.

Krippendorff, K. (2013). Content analysis: An introduction to its methodology, Third Edition. Washington, DC: Sage Publishing.

Lash, J. (1964). Eleanor Roosevelt: A friend's memoir. New York, NY: Doubleday Press.

Lathey, G. (2001). A havey-cavey business: Language in historical fiction with particular reference to the novels of Joan Aiken and Leon Garfield. In F. Collins \& Graham (eds.), Historical fiction for children: Capturing the past (32-42). London, UK: David Fulton Publishers.

Levine, L. (1977). Black culture and black consciousness: Afro-American fold thought from slavery to freedom. New York, NY: Oxford University Press.

Lindquist, D. (2009). The coverage of the Holocaust in high school history textbooks. Social Education, 73(6), 298-304.

Loewen, J. (1995). Lies my teacher told me: Everything your American history textbook got wrong. New York, NY: Simon and Schuster.

Loewen, J. (2010). Teaching what really happened: How to avoid the tyranny of textbooks and get students excited about doing history. New York, NY: Teachers College Press.

Logan, R. (1965). The betrayal of the Negro, from Rutherford B. Hays to Woodrow Wilson. New York, NY: Collier Books

Marable, M. (2011). Malcolm X: A life of reinvention. New York, NY: Penguin Books.

Matusevich, M. (2006). Strange Bedfellows: Censorship and history textbooks. Social Studies Research and Practice, 1(3), 359-373.

Maxwell, J. (2010). Using numbers in qualitative research. Qualitative Inquiry, 16(6), 475-482.

Metress, C. (2002). The lynching of Emmett Till: A documentary narrative. London, UK: University of Virginia Press.

National Council for the Social Studies (2013). College, career, and civic life (C3) framework for social studies state standards: Guidelines for enhancing the rigor of $k-12$ civics, economics, geography, and history. Silver Spring, MD: NCSS.

Nielsen, K. (2010). Beyond the Miracle Worker: The remarkable life of Anne Sullivan Macy and her extraordinary friendship with Helen Keller. New York, NY: Beacon Press.

Nokes, J. (2011). Recognizing and addressing the barriers to adolescents' "reading like historians." The History Teacher, 44(3) 379-404.

O'Farrell, B. (2011). She was one of us: Eleanor Roosevelt and the American worker. New York, NY: Cornell University Press. 
Parker, W. (2010). Listening to strangers: Classroom discussion in democratic education. Teachers College Record, 112(11), 2815-2832.

Pillow, W. (2003). Confession, catharsis, or cure? Rethinking the uses of reflexivity as methodological power in qualitative research. International Journal of Qualitative Studies in Education, 16(2), 175-196.

Pottker, J. (2005). Sara and Eleanor: The story of Sara Delano Roosevelt and her daughter-inlaw, Eleanor Roosevelt. New York, NY: St. Martin's Griffin.

Powers, C. (2003). Challenging the pluralism of our past: Presentism and the selective tradition in historical fiction written for young people. Research in the Teaching of English, 37, 425-466.

Robinson, J. \& Garrow, D. (1987). The Montgomery Bus Boycott and the women who started it: The memoir of Jo Ann Gibson Robinson. Knoxville: University of Tennessee Press.

Romano, R. \& Raiford, L. (2006). The civil rights movement in American memory. Athens, GA: The University of Georgia Press.

Roosevelt, E. (1961). The autobiography of Eleanor Roosevelt. New York, NY: Harper \& Brothers Publishers.

Rycik, M. \& Rosler, B. (2009). The return of historical fiction. The Reading Teacher, 63(2), 163166.

Salvatore, N. (2007). Eugene V. Debs: Citizen and socialist. Urbana, IL: University of Illinois Press.

Scharf, L. (1987). Eleanor Roosevelt: First Lady of American Liberalism. Boston, MA: Twayne Publishers.

Theoharis, J. (2013). The rebellious life of Mrs. Rosa Parks. Boston, MA: Beacon Press.

Thernstrom, S. (1964). Poverty and progress: Social mobility in a nineteenth century city. Cambridge, MA: Harvard University Press.

Waite, H. (1959). Valiant companions: Helen Keller and Anne Sullivan Macy. Philadelphia, PA: Macrae Smith Company.

Ware, S. (1984). Eleanor Roosevelt and democratic politics: Women in the postsuffrage era. In J. Hoff-Wilson \& M. Lightman's (eds.), Without precedent: The life and career of Eleanor Roosevelt (46-60). Bloomington, IN: Indiana University Press.

Williams, T. (2009). A closer look: The representation of slavery in the Dear America series. Social Studies and the Young Learner, 21(3), 26-29.

Wineburg, S. (1998). Reading Abraham Lincoln: An expert/expert study in the interpretation of historical texts. Cognitive Science, 22(3), 319-346.

Wineburg, S. (2001). Historical thinking and other unnatural acts: Charting the future of teaching the past. Philadelphia, PA: Temple University Press.

Wineburg, S. (2007). Unnatural and essential: The nature of historical thinking. Teaching History, 129, 6-11.

Wineburg, S. (2008). Goodbye Columbus. Smithsonian Magazine, 39(2), 98-104.

Wineburg, S. \& Martin, D. (2009). Tampering with history: Adapting primary sources for struggling readers. Social Education, 73(5), 212-216.

Wineburg, S., Martin, D., \& Monte-Sano, C. (2011). Reading like a historian: Teaching literacy in middle and high school history classrooms. New York, NY: Teachers College Press.

Wineburg, S. \& Monte-Sano (2008). Famous Americans: The changing pantheon of American 
heroes. Journal of American History, 93(2), 1186-1202.

Zaleski, J. \& Zinnel, V. (2013). Who writes history? Developing a social imagination with third graders. Social Studies and the Young Learner, 25(3), 23-26.

Zangrando, J. \& Zangrando, R. (1984). Eleanor Roosevelt and Black Civil Rights. In J. HoffWilson \& M. Lightman's (eds.), Without precedent: The life and career of Eleanor Roosevelt (88-107). Bloomington, IN: Indiana University Press.

\section{Web-Based References}

Bettmann, O. (1933, May 16). Eleanor Roosevelt visiting the Bonus Army camp. Retrieved from http://www.corbisimages.com/stock-photo/rights-managed/BE003028/eleanor-rooseveltvisiting-bonus-army-camp

Bickford, J. \& Wilton, M. (2012). Historicizing Christopher Columbus for elementary and secondary students. World History Connected, 9(2), 1-36. http://worldhistoryconnected.press.illinois.edu/9.2/bickford.html

Jackdaw Publications of Primary Source Documents. http://www.jackdaw.com

Historical Thinking Matters. Rosa Parks. Retrieved from http://historicalthinkingmatters.org/rosaparks/1/

Library of Congress. http://www.loc.gov/index.html

National Archives. Rosa Parks; Teaching with Documents: An Act of Courage, The Arrest Records of Rosa Parks. Retrieved from http://www.archives.gov/education/lessons/rosa-parks/

O’Malley, M. (2011, April 6). Performing government in the new deal. The Aporetic. Retrieved from http://theaporetic.com/?p=1468

Wilton, M. \& Bickford, J. (2012). An elementary school's spiraled curriculum on Columbus: A case study. Middle Ground Journal, 5, 1-30. Retrieved from http://resources.css.edu/academics/HIS/MiddleGround/articles/wilton.pdf 


\section{Appendix I - Children's Literature about Keller, Parks, and Roosevelt Helen Keller Book Titles \\ Adler, D. (1990). A picture book of Helen Keller. New York, NY: Holiday House. \\ Cline-Ransome, L. (2008). Helen Keller: The world in her heart. New York, NY: \\ HarperCollins \\ Publishers.}

Delano, M. (2008). Helen's eyes: A photobiography of Annie Sullivan, Helen Keller's teacher. Washington, DC: National Geographic.

Dubois, M. (2003). Helen Keller. Mankato, MN: Bridgestone Books.

Garrett, L. (2004). Helen Keller: A photographic story of a life. New York, NY: DK Publishing.

Garrett, L. (2013). Helen Keller. New York, NY: DK Publishing.

Kent, D. (2004). Helen Keller: Author and advocate for the disabled. Chanhassen, MN: The Child's World Publications.

Lakin, P. (2002). Helen Keller and the big storm. New York, NY: Aladdin Books.

Lawlor, L. (2001). Helen Keller: Rebellious spirit. New York, NY: Holiday House.

Lundell, M. (1995). A girl named Helen Keller. New York, NY: Scholastic Publishing.

Macleod, E. (2007). Helen Keller. Toronto, ON: Kids Can Press.

Miller, S. (2007). Miss Spitfire: Reaching Helen Keller. New York, NY: Atheneum Books for Young Readers.

Sullivan, G. (2007). Helen Keller: Her life in pictures. New York, NY: Scholastic.

Sutcliffe, J. (2002). Helen Keller. Minneapolis, MN: Millbrook Press.

Thompson, G. (2003). Who was Helen Keller? New York, NY: Grosset \& Dunlap.

\section{Rosa Parks Book Titles}

Adler, D. (1993). A picture book of Rosa Parks. New York, NY: Holiday House.

Edwards, P. (2005). The bus ride that changed history: The story of Rosa Parks. New York,

NY: Houghton Mifflin Company.

Giovanni, N. (2005). Rosa. New York, NY: Henry Holt and Company.

Greenfield, E. (1995). Rosa Parks. New York, NY: Harper Collins.

Kellaher, K. (2007). Rosa Parks: Civil rights pioneer. New York, NY: Harper Collins

Publishers.

Kittinger, J. (2010). Rosa's bus: The ride to civil rights. Honesdale, PA: Calkins Creek Press. Levine, M. (2005). Rosa Parks. North Mankato, MN: Compass Point Books.

Linde, B. (2012). Rosa Parks. New York, NY: Gareth Stevens Publishing.

Parks, R. \& Haskins, J. (1997). I am Rosa Parks. London, England: Penguin Books.

Pingry, P. (2007). The story of Rosa Parks. Nashville, TN: CandyCane Press.

Pingry, P. (2008). Meet Rosa Parks. Nashville, TN: Ideals Children's Books.

Pinkney, A. (2008). Boycott blues: How Rosa Parks inspired a nation. New York, NY:

Greenwillow Books.

Reynolds, Aaron (2010). Back of the bus. New York, NY: Philomel Books.

Ringgold, F. (1999). If a bus could talk: The story of Rosa Parks. New York, NY: Aladdin Books.

Schaefer, L. (2002). Rosa Parks. Mankato, MN: Pebble Books.

Eleanor Roosevelt Book Titles 
Adler, D. (1991). A picture book of Eleanor Roosevelt. New York, NY: Holiday House. Cooney, B. (1996). Eleanor. New York, NY: Puffin Books.

DeYoung, C. (1999). A letter to Mrs. Roosevelt. New York, NY: Random House Children's Books.

El Nabli, D. (2006). Eleanor Roosevelt: First Lady of the world. New York, NY: Harper Collins Publishers.

Ellwood, N. (1999). Learning about integrity from the life of Eleanor Roosevelt. New York, NY: PowerKids Press.

Feinberg, B. (2003). Eleanor Roosevelt. Brookfield, CT: The Millbrook Press, Inc.

Fleming, C. (2005). Our Eleanor: A scrapbook look at Eleanor Roosevelt's remarkable life. New York, NY: Atheneum Books for Young Readers.

Freedman, R. (1993). Eleanor Roosevelt: A life of discovery. New York, NY: Clarion Books.

Koestler-Grack, R. (2004). The story of Eleanor Roosevelt. Philadelphia, PA: Chelsea Clubhouse Publishers.

Kulling, M. (1999). Eleanor everywhere: The life of Eleanor Roosevelt. New York, NY:

Random House Publishing.

Rappaport, D. (2009). Eleanor: Quiet no more. New York, NY: Hyperion Books.

Santow, D. (1999). Anna Eleanor Roosevelt. New York, NY: Children's Press.

Thompson, G. (2004). Who was Eleanor Roosevelt? New York, NY: Grosset and Dunlap.

Vercelli, J. (1995). Eleanor Roosevelt: Human rights advocate. New York, NY: Chelsea

House Publishers.

Winner, D. (2004). Eleanor Roosevelt. New York, NY: Blackbirch Press.

\section{Author Bios}

John H. Bickford III is a former Mid-Prairie (IA) Middle School social studies teacher and current Assistant Professor of Elementary and Middle Level Education at Eastern Illinois University. He has teaching and research interests in elementary students' historical thinking/literacy and authentic social studies instruction/assessment for middle level students. Email: jbickford@eiu.edu.

Cynthia W. Rich is Director of the Library of Congress Teaching with Primary Sources program at Eastern Illinois University. With a background in language arts, her teaching and research interests include classroom integration of primary source material and oral history collection. 